\title{
Emerging Role of Cellular Prion Protein in the Maintenance and Expansion of Glioma Stem Cells ${ }^{\dagger}$
}

\author{
Stefano Thellung ${ }^{1}$, Alessandro Corsaro ${ }^{1}$, Alessia G. Bosio ${ }^{1}$, Martina Zambito ${ }^{1}$, \\ Federica Barbieri ${ }^{1}$ (D), Michele Mazzanti ${ }^{2, *(\mathbb{D})}$ and Tullio Florio $1,3, *$ (D) \\ 1 Sezione di Farmacologia, Dipartimento di Medicina Interna \& Centro di Eccellenza per la Ricerca \\ Biomedica (CEBR), Università di Genova, 16132 Genova, Italy; stefano.thellung@unige.it (S.T.); \\ ale.corsaro@unige.it (A.C.); alegbosio@gmail.com (A.G.B.); zambito.martina@yahoo.com (M.Z.); \\ federica.barbieri@unige.it (F.B.) \\ 2 Dipartimento di Bioscienze, Università di Milano, 20133 Milano, Italy \\ 3 IRCCS Ospedale Policlinico San Martino, 16132 Genova, Italy \\ * Correspondence: tullio.florio@unige.it (T.F.); michele.mazzanti@unimi.it (M.M.); Tel.: +39-01-0353-8806 (T.F.); \\ +39-02-5031-4958 (M.M.) \\ + Running title: Cellular prion protein and glioma development.
}

Received: 30 October 2019; Accepted: 13 November 2019; Published: 18 November 2019

\begin{abstract}
Cellular prion protein $\left(\mathrm{PrP}^{\mathrm{C}}\right)$ is a membrane-anchored glycoprotein representing the physiological counterpart of $\operatorname{PrP}$ scrapie $\left(\mathrm{PrP}^{\mathrm{Sc}}\right)$, which plays a pathogenetic role in prion diseases. Relatively little information is however available about physiological role of $\operatorname{Pr}^{\mathrm{C}}$. Although $\operatorname{Pr} \mathrm{P}^{\mathrm{C}}$ ablation in mice does not induce lethal phenotypes, impairment of neuronal and bone marrow plasticity was reported in embryos and adult animals. In neurons, $\operatorname{PrP}^{\mathrm{C}}$ stimulates neurite growth, prevents oxidative stress-dependent cell death, and favors antiapoptotic signaling. However, $\mathrm{PrP}^{\mathrm{C}}$ activity is not restricted to post-mitotic neurons, but promotes cell proliferation and migration during embryogenesis and tissue regeneration in adult. $\operatorname{PrP}^{\mathrm{C}}$ acts as scaffold to stabilize the binding between different membrane receptors, growth factors, and basement proteins, contributing to tumorigenesis. Indeed, ablation of $\mathrm{PrP}^{\mathrm{C}}$ expression reduces cancer cell proliferation and migration and restores cell sensitivity to chemotherapy. Conversely, $\mathrm{PrP}^{\mathrm{C}}$ overexpression in cancer stem cells (CSCs) from different tumors, including gliomas-the most malignant brain tumors-is predictive for poor prognosis, and correlates with relapses. The mechanisms of the $\operatorname{PrP}^{\mathrm{C}}$ role in tumorigenesis and its molecular partners in this activity are the topic of the present review, with a particular focus on $\mathrm{PrP}^{\mathrm{C}}$ contribution to glioma CSCs multipotency, invasiveness, and tumorigenicity.
\end{abstract}

Keywords: cellular prion protein; glioma; cancer stem cells; intracellular signaling

\section{Introduction}

The discovery of molecules with pleiotropic functions in heterogeneous pathophysiologic conditions, is a common event in cell biology. A relevant example of such molecules is the cellular prion protein $\left(\operatorname{PrP}^{\mathrm{C}}\right)$, the physiological counterpart of the pathogenic prion protein scrapie $\left(\operatorname{PrP}^{\mathrm{Sc}}\right)$. Its name was introduced by Stanley B. Prusiner to indicate the proteinaceous etiologic agent of Scrapie, an endemic and infective neurodegenerative disorder of sheep, representing the prototype of prion diseases, also known as transmissible spongiform encephalopathies (TSEs) [1]. Until a few years ago, $\mathrm{PrP}^{\mathrm{C}}$, whose precise physiological role is still debated, was almost exclusively associated with the development of TSEs after its tridimensional conformation alteration [2-4]. However, recently a possible key role of $\mathrm{PrP}^{\mathrm{C}}$ in tissue plasticity, embryogenesis, and cancer development is also emerging [5]. $\mathrm{PrP}^{\mathrm{C}}$ plays a central role in the development of TSEs, being expression in neurons, 
immunocompetent cells, and peripheral organs, crucial for the neuro-invasion by the infective $\operatorname{Pr} \mathrm{P}^{\mathrm{Sc}}$ counterpart, and for the consequent neuronal death. In the absence of $\operatorname{PrPC}^{\mathrm{C}}$, cells become resistant to prion infection, brain propagation, and neurodegeneration [6-8]. Several potential roles for $\operatorname{PrPC}$ in adult central and peripheral nervous systems (CNS and PNS) were proposed. For example, as far as $\mathrm{PrP}^{\mathrm{C}}$ homeostatic role in PNS, its axonal expression was reported to be required to peripheral myelin maintenance [9], but a definitive role has yet to be proved. On the other hand, a required-to-life role for $\operatorname{PrP}^{\mathrm{C}}$ is still unclear: transgenic mice in which $\operatorname{PrP}^{\mathrm{C}}$ expression was ablated do not evidence lethal abnormalities in adult life [10,11], although alterations in neural development were reported [12]. Remarkable efforts have been performed to identify differential pattern of tissue expression of $\operatorname{PrP}^{\mathrm{C}}$ in mammals, evidencing the highest expression within CNS and PNS, followed by lymphoid organs, bone marrow (BM) hematopoietic cells, and circulating monocytes [13-18]. $\mathrm{PrP}^{\mathrm{C}}$ expression increases along with postnatal growth, but can be identified, at lower level, also in embryonic nerve tissue, particularly in the late stages of pre-natal development [19-21]. Analogously, $\operatorname{PrP}^{\mathrm{C}}$ is expressed in pluripotent cells, including neuron and glial precursors, hematopoietic and mesenchymal progenitors, both in embryos and in adults, suggesting a potential role of such protein in driving ontogenesis and maintenance of tissue homeostasis $[12,22,23]$. Importantly, the identification of $\operatorname{PrP}^{\mathrm{C}}$ expression in stem cells could be at the basis of the observation that the absence of $\operatorname{PrP}^{C}$ induces some abnormalities during the brain development as well as in the self-renewal capability of hematopoietic stem cells [24-29].

Given the peculiar topology of $\operatorname{PrP}^{C}$ and the very high levels of expression with the CNS, it has long been hypothesized that it could represent an adaptor molecule for putative neuroprotective factors. Indeed, a growing number of extracellular ligands and extracellular matrix (ECM) proteins are recently known to form multimers in which $\mathrm{PrP}^{\mathrm{C}}$ acts as scaffold [30].

Finally, at the beginning of the twenty-first century, $\operatorname{PrPC}^{\mathrm{C}}$ also became a relevant player in the oncology field. In fact, evidence was provided about a relevant role of $\operatorname{PrP}^{\mathrm{C}}$ in tumorigenesis, cancer progression, acquisition of multidrug resistance (MDR), and metastatic propagation [31-33].

Gliomas are malignant astrocytic brain tumors that, according to the World Health Organization (WHO), are classified as grade I (pilocytic astrocytoma), grade II (diffuse astrocytoma/oligodendroglioma), grade III (anaplastic astrocytoma/oligodendroglioma), and grade IV (glioblastoma) [34]. Glioblastoma (GBM) is the most aggressive primary brain tumor with a poor prognosis even after multimodal therapeutic approaches [35]. In fact, GBM rapidly relapses after surgical resection, and is able to resist radio- and chemo-therapies. Several hypotheses, not reciprocally exclusive, have been proposed to determine which cell population gives origin to gliomas [36]. It was reported that malignant transformation can occurs even from mature astrocytes, and neurons, which undergo dedifferentiation [37]. However, in most cases, gliomas might arise from tumor transformation of neural stem cells (NSCs) or committed neural progenitors, along their differentiation path into the subventricular zone $[38,39]$. In fact, as observed in many other solid tumors, a major cause of GBM development, aggressiveness and relapse is the presence, within the tumor mass, of multipotent cells from which more differentiated cells origin to form the bulk of tumor mass. These poorly differentiated cells grow into specific stem cell microenvironments called tumor niches, which contain heterogeneous cell populations including, beside tumor-promoting stem-like cells, ependymal and endothelial cells, astrocytes, and immune system cells. These tumorigenic cell subpopulations have been named glioblastoma stem cells (GSCs), because somehow represent the pathogenic counterpart of normal neural stem cells (NSCs) [40,41]. As most of the normal stem cells, GSCs display low proliferation rate, self-renewal capability, high activity of DNA-repair machinery and drug extrusion pumps, allowing them to survive to the toxicity of most conventional chemotherapies and provide, upon differentiation, a continuous cellular supply to the tumor mass (see [42] for a specific review). Being GSCs the major cause of tumor relapse and pharmacologic resistance, increasing efforts are currently addressed to identify the cellular determinants that account for their self-renewal capacity.

Interestingly, GSCs were reported to be high dependent on $\mathrm{PrP}^{\mathrm{C}}$ to:

maintain tumor-initiating activity, 
(ii) sustain proliferation and invasiveness,

(iii) acquire multidrug resistance, and

(iv) preserve multipotency and ability to differentiate in non-tumorigenic glioma cells [43-46]. Finally, as observed in normal tissues, in CSCs $\mathrm{PrP}^{\mathrm{C}}$ seems to act as receptor or scaffold protein for several extracellular signals dealing with maintenance of self-renewal, adherence, invasiveness, and migration of cells [47].

This review aims to collect and critically analyze the most recent discoveries about the role of $\operatorname{PrPC}$ in cancer development and progression, particularly focusing on gliomas and GSCs, and to analyze the possible role of $\mathrm{PrP}^{\mathrm{C}}$ as a target candidate for novel therapeutic approaches.

\section{The Cellular Prion Protein}

$\mathrm{PrPC}$, encoded by the PRNP gene, is an extracellular syaloglycoprotein, highly enriched in neurons, that is tethered to the outer leaflet of plasma membrane by a glycosylphosphatidyl-inositol (GPI) anchor [48]. It is structured by an $\alpha$-helix rich C-terminus, and an unstructured $\mathrm{N}$-terminus tail. In TSEs, $\mathrm{PrP}^{\mathrm{C}}$ undergoes a structural alteration generating a pathogenic isoform $\left(\mathrm{PrP}^{\mathrm{Sc}}\right)$ in which a significant part of the unstructured tail is converted in $\beta$-structures $[1,49]$. This alteration allows $\mathrm{PrP}^{\mathrm{Sc}}$ to become protease-insensitive, forming intra- and extracellular aggregates responsible of neuronal death. $\mathrm{PrP}^{\mathrm{Sc}}$ generation is not limited to Scrapie, but is the pathogenic mechanism of all fatal, albeit rare, human prion diseases including Kuru, fatal familiar insomnia, Gerstmann-Straussler-Sheinker, and Creutzfeldt Jacob diseases. These forms have sporadic, inherited, and infectious etiologies in which $\mathrm{PrP}^{\mathrm{C}}$ either spontaneously converts into $\mathrm{PrP}^{\mathrm{Sc}}$ form, bear conversion-favoring mutations, or bind to exogenous $\mathrm{PrP}^{\mathrm{Sc}}$ which acts as a template, respectively [1]. The peculiarity of TSEs is their infective behavior, since $\mathrm{PrP}^{\mathrm{Sc}}$ can interact with newly synthesized $\mathrm{PrPC}^{\mathrm{C}}$ causing its conversion into the pathological isoform, favoring the spreading of the neurodegenerative lesions. A very recent and intriguing theory proposes that similar pathogenic activity induced by protein misfolding occurs independently from the specific protein involved, in TSEs as well as in other more common and fatal neurodegenerative disorders of the central nervous system including Alzheimer's, Parkinson's, and Huntington's diseases and amyotrophic lateral sclerosis [50-54]. In this context, $\operatorname{PrP}^{\mathrm{C}}$ was proposed to represent the cellular receptor for $\mathrm{A} \beta$ and tau in Alzheimer disease, and $\alpha$-synuclein in Parkinson disease, being these interactions required for the different misfolded protein neuronal internalization and neurotoxicity [55-58]. Moreover, the biological activity of oligomers from the different misfolded proteins responsible of all these neurodegenerative diseases, was evaluated using different disease models in vitro and reported to activate similar proapoptotic and gliotrophic pathways [59-64]. In particular, data using purified $\mathrm{PrP}^{\mathrm{Sc}}$ or amyloidogenic $\mathrm{PrP}^{\mathrm{Sc}}$-mimicking peptide models demonstrated the activation of p38 MAP kinase, excitotoxicity via NMDA receptors and dysregulation of $\mathrm{Ca}^{+2}$ homeostasis or autophagy to be the main neurotoxic activity on neurons, while the same treatments caused activation of astrocytes and microglia leading to proliferation via ERK1/2 MAP kinase and release of cytokines, chemokines, prostaglandins and nitric oxide [62,65-74]. In another experimental setting, ERK1/2 MAP kinase activity, relocated in the cytosol, was shown to favor prion replication, while JNK activity counteracted the formation of prions [75,76].

Given its widespread expression among mammals, it is reasonable that $\operatorname{PrP}^{\mathrm{C}}$ plays a significant role in brain and other organs functioning that extends beyond sensitivity to prion illness, driving critical processes for the physiology of the nervous and immunity systems. Although $\operatorname{PrP}^{\mathrm{C}}$ ablation does not induce lethal phenotypes, important evidence showed that nervous tissue development during embryogenesis, as well as the maintenance of hematopoietic and mesenchymal pluripotent cells in adult mammals, requires the presence of $\mathrm{PrP}^{\mathrm{C}}$ on the cell surface $[9-12,22,28,77]$. 


\section{Physiology of $\operatorname{PrP}^{\mathrm{C}}$ in the Development and Homeostasis of Normal Tissues}

Mammalian $\operatorname{PrP}^{\mathrm{C}}$ is mostly expressed in the CNS where it becomes detectable at late stages of embryonal development and strongly increases shortly after birth, though maintaining a marked heterogeneity among different brain areas [19], under the control of nerve growth factor activity [78]. Noteworthy, $\operatorname{PrP}^{\mathrm{C}}$ mRNA is detectable, although at lower levels, also along peripheral nerves and ganglia and in the sensory neurons as gut plexus, olfactory membrane and retina [19]. Beyond the nervous system, the expression of $\mathrm{PrPC}^{\mathrm{C}}$ is also detectable in adult bone marrow, lymphoid organs, heart, skeletal muscles, and lung [79,80]. Altogether, these data strongly indicated that neuronal and hematopoietic systems may particularly rely on $\mathrm{PrPC}^{\mathrm{C}}$ for their development, survival, and homeostasis.

\subsection{Role of $\operatorname{Pr}^{\mathrm{C}}$ in the Development of the Nervous System}

During the embryonic development of neural tube, and in the limited process of adult neurogenesis, pluripotent stem cells and neural precursors differentiate into neuronal and glial lineages [19,81-83]. In light of the potential role of $\mathrm{PrP}^{\mathrm{C}}$ as a scaffold that engages different soluble and/or membrane factors, stabilizing ligand-receptor links [84-86], it was proposed that $\mathrm{PrP}^{\mathrm{C}}$ may work either as a receptor or an adaptor that accompanies embryonic cells through neural differentiation and migration. The enrichment of $\mathrm{PrP}^{\mathrm{C}}$ into lipid rafts and the growing number of soluble ligands or plasma membrane and $\mathrm{ECM}$ molecules able to interact with $\mathrm{PrPC}^{\mathrm{C}}$ led to the hypothesis that this protein might be involved in cell adhesion to other cells or ECM. A growing number of soluble ligands or plasma membrane and ECM molecules have been studied for their capability to interact with $\operatorname{PrP}^{C}$ [87] (Figure 1).
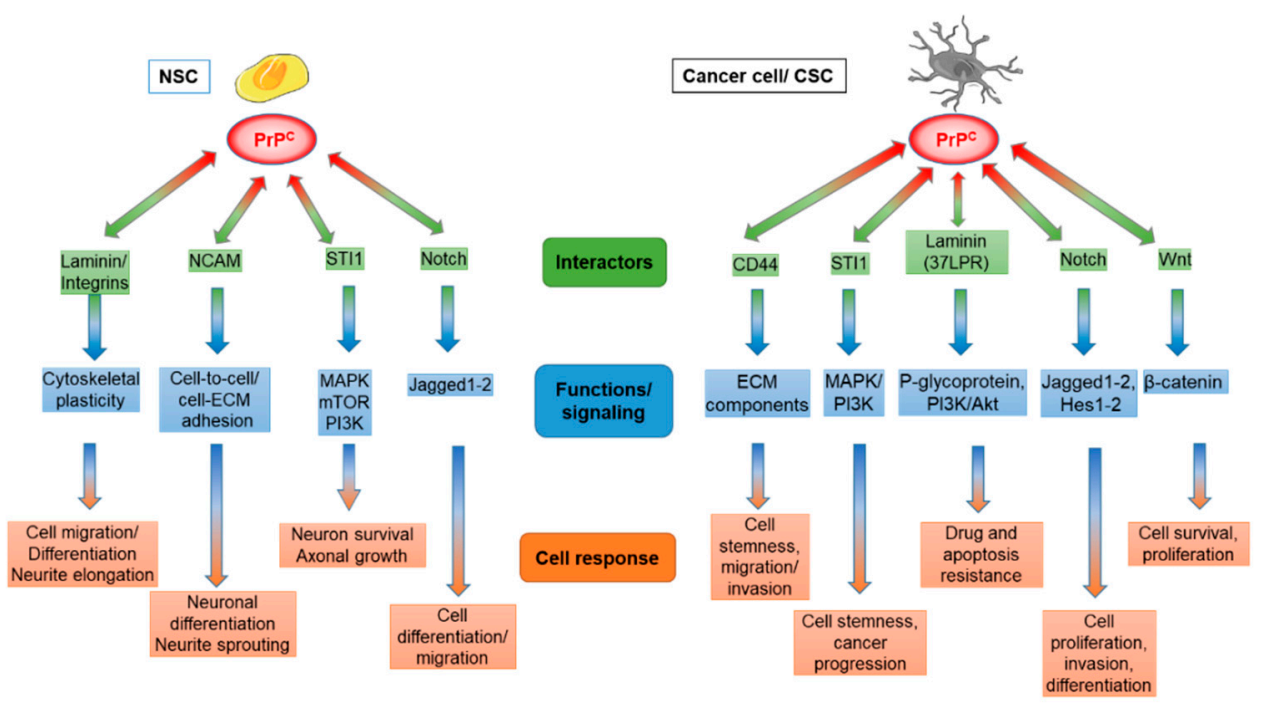

Figure 1. Comparison of cellular prion protein $\left(\mathrm{PrP}^{\mathrm{C}}\right)$ engagement to multiple pathways in neural stem cells (NSCs), and cancer/cancer stem cells (CSCs). Partially overlapping interacting proteins between NSCs and CSCs were reported, although the interaction can determine different cell responses (orange in the figure). Abbreviations: NCAM: neural cell adhesion molecule; STI1: stress-inducible protein 1; 37LPR: 37-kDa laminin receptor; ECM: extracellular matrix; MAPK: mitogen-activated protein kinase; PI3K: phosphatidylinositol-3-Kinase; mTOR: mammalian target of rapamycin; Wnt: Wingless-related integration site family; Akt: Protein Kinase B; Hes1-2: hairy and enhancer of split 1-2.

Among the different actors controlling cell shape and migration during embryogenesis and neuron regeneration in adults, particular relevance is held by adhesion proteins [88]. Laminins are heterotrimeric proteins expressed on basement membrane which, interacting with members of the integrin family, control the plasticity of cytoskeleton proteins $[88,89]$. In neurons, this interaction plays fundamental importance in embryonal development of neural system while, in adults, it models cell shape, migration, and neurite expansion or regeneration. The laminin-integrin system recognizes $\operatorname{Pr} \mathrm{PC}^{\mathrm{C}}$ 
as a cofactor that can act either through direct binding to laminin or as a scaffold that regulates integrin signaling $[90,91] . \mathrm{PrP}^{\mathrm{C}}$ also interacts with the non-integrin $37 \mathrm{kDa}$ laminin receptor precursor (37LRP) on the cell surface $[90,92-96]$. Both laminin- $\mathrm{PrP}^{\mathrm{C}}$ and $37 \mathrm{LRP}-\mathrm{PrP}^{\mathrm{C}}$ binding are specific and recognize the same domain of $\operatorname{PrP}^{\mathrm{C}}$. In the absence of $\operatorname{PrP}^{\mathrm{C}}$ expression, the proper interactions between basement laminin and cell membrane are impaired, resulting in abnormalities in cell differentiation, particularly affecting neuritogenesis and axonal growth [90-92].

Another plasma membrane protein involved in neural differentiation and plasticity is the neural cell adhesion molecule (NCAM). NCAM is expressed by neurons and glial cells allowing their adhesion to ECM [97]. Prusiner's group reported, through the isolation of $\operatorname{PrP}^{\mathrm{C}}$-containing lipid rafts, the presence of high molecular mass protein complexes in which the major component is NCAM [98]. Following studies confirmed that NCAM and $\mathrm{PrP}^{\mathrm{C}}$ coexist within lipid rafts establishing a specific binding $[99,100]$. It was proposed that NCAM recruitment by $\operatorname{PrP}^{\mathrm{C}}$ serves as a signal to promote neuronal precursor differentiation [101,102], neurite sprouting, and elongation through the activation of Fyn-dependent pathways [98,103].

Beyond adhesion molecules, transmembrane and secreted proteins are recently recognized to play a role in nervous system plasticity. Among these, stress induced protein 1 (STI1) and Notch complex are emerging as $\mathrm{PrP}^{\mathrm{C}}$ interactors. Stress-inducible protein 1 (STI1), also known as Hsp70-Hsp90 organizing protein (HOP), acts a co-chaperonin involved in protein folding. STI1 is mainly expressed as transmembrane protein in neurons, although its secretion from glial cells has also been described. Importantly, this protein displays a specific amino acidic domain specifically recognized by $\mathrm{PrPC}^{\mathrm{C}}$ [104], and their interaction supports neuronal survival and axonal growth [105]. In particular, upon $\mathrm{PrP}^{\mathrm{C}}$ binding STI1 is retained on cell surface to sustain neuritogenesis and cell survival through the activation of mitogen-activated protein kinase (MAPK) and protein kinase A (PKA), respectively [106,107]. Moreover, PrPC/STI1 binding sustains mTOR-dependent protein synthesis through the maintenance of the PI3 kinase-dependent mTOR phosphorylation $[107,108]$ Importantly, NSC self-renewal is also dependent on $\operatorname{PrPC}^{\mathrm{C}} / \mathrm{STI} 1$ interaction, since neural progenitors from $\operatorname{PrP}^{\mathrm{C}}$ null mice, or in which $\mathrm{PrP}^{\mathrm{C}}$ or STI1 were blocked by antibodies, are less able to ensure self-renewal in vitro even in the presence of exogenously added STI1 [109].

Notch1 is a transmembrane protein that contributes to maintain the stemness of neuronal progenitors and to drive the migration of neuronal and glial progenitor cells in embryonal and postnatal brain $[110,111]$. It has been demonstrated that $\mathrm{PrP}^{\mathrm{C}}$ depletion in neuroectodermal cells, neuronal stem cells, and in mice embryos produced a down-regulation of Notch 1 receptor and its cognate ligands, Jagged 1 and 2, and of the expression of target genes including nestin, OLIG2 and N-cadherin, depicting a molecular scenario in which $\mathrm{PrPC}^{\mathrm{C}}$ plays a pivotal role in stemness and self-renewal of NSCs [112].

\section{2. $\operatorname{Pr} P^{C}$ Stimulates Hematopoiesis}

Early studies on $\mathrm{PrP}^{\mathrm{Sc}}$ infectivity showed that prion neuroinvasion is preceded by its accumulation in spleen, lymph nodes, thymus, and follicular dendritic cells (FCDs), which represent a relevant site where $\operatorname{PrPSc}$ binds $\operatorname{PrPC}^{\mathrm{C}}$ to induce its conversion into the pathologic conformation $[15,113,114]$. Remarkably, immunodeficient mice are resistant to $\mathrm{PrP}^{\mathrm{Sc}}$ passage from periphery to the brain but $\mathrm{BM}$ restoration can reintroduce the capacity of $\mathrm{PrP}^{\mathrm{Sc}}$ to replicate into the mice spleen after intracerebral or peripheral inoculation. These observations clearly indicate the importance of the immune cells in TSE pathogenesis [6,115-118]. Beyond $\mathrm{FDCs}, \mathrm{PrP}^{\mathrm{C}}$ is expressed in hematopoietic cells including myeloid dendritic cells (DC) and, at a lower level, in circulating blood cells as erythrocytes, platelets, and B and $\mathrm{T}$ lymphocytes and monocytes, although still discordant reports were produced on the latter cell populations $[13,80,119]$. It is hence reasonable to hypothesize a role of $\operatorname{PrP}^{C}$ in the immune system functionality and development. The ablation of $\mathrm{PrPC}^{\mathrm{C}}$ in mice produces only minor abnormalities in the mature immune system as alteration in monocytes/neutrophils ratio and in DC-T lymphocytes cross-activation, although it does not cause immunodeficiency [120,121]. However, the lack of $\operatorname{PrPC}$ 
is detrimental under prolonged stressful conditions as can be experimentally induced after serial bone marrow transplantation in irradiated animals. Under these conditions, the presence of $\operatorname{PrP}^{\mathrm{C}}$ is necessary for the regeneration of hematopoietic cells [28]. Moreover, the expression of $\mathrm{PrP}^{\mathrm{C}}$ in myeloid progenitors increases after total body irradiation, and post-irradiation recovery of hematopoietic stem cells is hampered in $\mathrm{PrP}^{\mathrm{C}}$-null mice [122]. These studies indicate that $\operatorname{PrP}^{\mathrm{C}}$ is highly expressed in $\mathrm{BM}$ stem cells of mesenchymal and hematopoietic origin, where, in analogy with NSCs, it sustains their indefinite self-renewal. $\mathrm{PrP}^{\mathrm{C}}$ expression is inducible by stressful conditions in order to sustain the capacity of BM hematopoietic cells to replenish the pools of circulating mature blood cells.

\section{4. $\operatorname{PrP}^{\mathrm{C}}$ and Cancer Stem Cells in Gliomas and Other Tumors}

Metastasization, the capacity of neoplastic cells to detach from a primary tumor mass, diffuse through blood and lymph streams, and form tumor colonies in distant body areas, is one of the main causes of cancer deaths. Metastatic cells often display an enhanced proliferation rate, self-repair capacity, and insensitivity to conventional chemio- and radiotherapy. In CNS malignant solid tumors, such as GBM, fatal outcome is caused by the rapid invasion of brain parenchyma that causes tumor relapse, even after extensive reduction of the mass induced by surgical and chemo-radiotherapy. The current hypothesis to explain cancer's ability to relapse post-surgery and resist cytotoxic drug treatment, indicates that tumor development and progression is sustained by a minority of cells that combine malignant transformation with stem-like multipotency. These cancer stem cells (CSCs) divide indefinitely and originate non-stem differentiated cells that form the bulk mass of tumors $[5,40,41,123]$. CSCs theory states that alterations of maturation and self-renewal of organ-specific stem cells could be the main factor at the basis of tumorigenesis. Virtually any kind of tumor, even benign in nature [124] possibly contains CSCs. Notably, CSCs display a high MDR efficiency that, altogether with the low proliferation rate and self-renewal capability, confers resistance to conventional chemotherapy. Since CSCs fuel, upon differentiation, a continuous supply of cells to the tumor mass, it is conceivable that they represent the most notable target for really effective cancer eradicating therapies.

Present in virtually all types of gliomas, CSCs are particularly relevant for the rapid recurrence and dissemination of GBM, whence they have been named GBM stem cells (GSCs) [41,125,126]. GBM is characterized by heterogeneous cell populations comprising GSCs and non-stem cancer cells, intermingled with multiple cell types such immune cells (microglia, peripheral macrophages, leukocytes, CD4+ T cells, and Treg), pericytes, and endothelial cells recruited from non-tumor vasculature or by trans-differentiated GSCs, and includes necrotic areas forming a complex microenvironment [127-129]. GSCs are functionally resident in niches, due to the homing activity of the chemokine CXCL12 produced by stromal cells [130], whose microenvironment protects them by external insults, including cytotoxic drugs, and favor their maintenance of stemness. GBM niches have been currently characterized in five different typologies, of which the best characterized is the perinecrotic hypoxic niche, in which the relative scarcity of oxygen sustains GSC stemness, and the perivascular niche in which GSCs contribute to the neovascularization of the tumor mass and form which they migrate to distant brain areas [131,132]. Thus, GBM development proceeds by misleading the same pathways that sustain NSCs in brain sub-ventricular zone [42,132].

The characterization of the cellular mechanisms involved in GSC balance between maintenance of stemness and self-renewal capacity, and the differentiation in non-stem tumor cells, represents an extremely challenging issue with potential therapeutic value, though still largely unmet. Particularly complex is also the definition of those elements that mediates GSCs contact with extracellular ligands or with surrounding cells to modulate their self-renewal or differentiation.

Given its peculiar topology on the cell surface, $\mathrm{PrP}^{\mathrm{C}}$ may act as a receptor for extracellular ligands and proteins, which interacting with the plasma membrane or basement matrix, transduce cell responses favoring cancer development and progression, including enhancement of protein synthesis, apoptosis blockade, maintenance of multipotency, detachment from extracellular membrane, and acquisition of MDR. One of the first indications concerning the relevance of $\operatorname{PrP}^{\mathrm{C}}$ in cancer biology 
dates back to the studies by Fan et al., which demonstrated the overexpression of $\operatorname{PrP}^{\mathrm{C}}$ in gastric carcinomas and gastric cancer cell line, that was correlated with doxorubicin resistance and a highly invasive behavior in vivo $[33,133]$. $\mathrm{PrP}^{\mathrm{C}}$-dependent resistance to doxorubicin was showed to be mediated by the expression of P-glycoprotein, a main effector of MDR, and the increase in the Bcl-2/Bax ratio [31]. Similarly, in colorectal and breast cancers, $\operatorname{PrP}^{\mathrm{C}}$ expression level was shown to be predictive of resistance to chemotherapy, metastatic behavior and, in general, poorer prognosis $[31,44,134,135]$.

$\operatorname{PrP}^{C}$ is expressed at high levels also in glioma tissues $[107,136]$ and cell lines $[137,138]$, and cells from this tumor histotype were reported to be dependent on the presence of $\mathrm{PrP}^{\mathrm{C}}$ to proliferate and acquire multidrug resistance [139]. The expression of $\mathrm{PrP}^{\mathrm{C}}$ was also analyzed in patient-derived GSC-enriched cultures that are able to continuously grow in stem cell-permissive, EGF/bFGF-containing medium [43]. Among GSC features, these cultures evidenced the capacity to grow as neurosphere, an in vitro index of self-renewal, and, when intracranially injected into immunodeficient mice, are able to develop tumors which reproduce the characteristics of the original GBM. In this study, several evidences supported the role of $\operatorname{PrP}^{\mathrm{C}}$ in the tumorigenic activity of GSCs: on one hand $\operatorname{PrP}^{\mathrm{C}}$ protein levels were directly correlated to the in vitro proliferation rate of these cells, and, on the other, most of GSC-like cellular behaviors were strongly affected by $\operatorname{PrP}^{\mathrm{C}}$ silencing. Down-regulation of $\operatorname{PrP}^{\mathrm{C}}$ reduced cell growth, clonogenensis and spherogenesis activities, and the ability to develop tumors in animal models [43]. Phenotypically the loss of GSC-like activity was associated with the down-regulation of stem cell marker expression (e.g., Sox2 and Nanog) in favor of differentiation markers, such as glial fibrillary acidic protein (GFAP) [43]. Similarly, it was also shown that stem-like cells derived from established GBM cell lines (U87, U251) contain higher levels of $\operatorname{PrP}^{\mathrm{C}}$ than the GBM differentiated cell counterpart [137].

These data suggest that the presence of $\operatorname{PrP}^{C}$ is critical to maintain of GSC stemness and that its reduction could represent a strategy to force GSC shift towards more chemotherapy-sensitive and differentiated cancer cells.

Another major reason for GBM relapse after adjuvant chemotherapy is the selection, induced by the pharmacological treatment, of GSCs with increased DNA-repairing and antiapoptotic capacities. For example, this phenomenon was observed after treatment with the alkylating agent temozolomide (TMZ), the most commonly used cytotoxic drug for GBM [140,141]. It was observed that, after TMZ treatment of recurrent GBM samples, $\mathrm{PrP}^{\mathrm{C}}$ expression is increased, possibly contributing to the acquisition of resistance through the binding and inhibition of nuclear translocation of the transcriptional receptor prostate apoptosis response-4 (Par-4) [45], which normally favors apoptosis via the inhibition of the anti-apoptotic protein $\mathrm{Bcl} 2$ [142]. Importantly, the down-regulation of $\operatorname{PrPC}$ restores Par-4 activity and GBM sensitivity to TMZ [45].

Acknowledging the ability of $\operatorname{PrP}^{\mathrm{C}}$ to interact with several NSC receptors involved in the control of self-renewal and differentiation, the role of $\mathrm{PrP}^{\mathrm{C}}$ interaction with stemness-related ligands in GSCs proliferation, invasiveness, and drug resistance has become a major topic of research and is currently under intense investigation. Indeed, a growing number of interactors has been recently identified and proposed to promote GBM malignancy through their co-operation with $\mathrm{PrP}^{\mathrm{C}}$, also suggesting that $\operatorname{PrP}^{\mathrm{C}}$ itself could become a relevant target for therapies specifically directed against the CSC subpopulation [47] (Figure 1). Some of the most extensively studied $\mathrm{PrP}^{\mathrm{C}}$-interacting molecules in cancer cells and, in particular, in CSCs are discussed below.

\section{1. $\operatorname{Pr} P^{C}$ and $C D 44$}

CD44 is a transmembrane glycoprotein originally described in lymphocytes [143], that functions as adhesion protein to the ECM components hyaluronic acid, fibronectin, and laminin. Although expressed in a wide variety of normal cells, CD44 is overexpressed in cancer cells, including CSCs, in which favors cell survival via hyaluronic acid binding and allowing distant tissue homing after metastasization [144]. In GBM, CD44 is highly expressed in GSCs lying into niches, and it is regarded as a marker for a poor prognosis [145-147]. A definite role of CD44 in sustaining GSC activity is still to 
be determined and it has been proposed that it may vary according to the location of CD44-positive GSCs within the tumor mass: CD44 is involved in the control of stemness in the cells present in hypoxic niches, while it favors their tissue dissemination if it is predominant in perivascular niche GSCs [148-150].

Although no evidence is presently available about a CD44- $\operatorname{PrP}^{\mathrm{C}}$ direct interaction in GBM, such interaction has been demonstrated in gastric and colorectal cancers $[33,44]$, where it allows the formation of metastasis. Moreover, both $\mathrm{CD} 44$ and $\mathrm{PrP}^{\mathrm{C}}$ are overexpressed in breast cancer cell lines resistant to doxorubicin, and $\operatorname{PrPC}^{\mathrm{C}}$ silencing, disrupting this interaction, allows the recovery of drug sensitivity. Similarly, in breast carcinoma tissues, a direct correlation between the overexpression of both CD44 and $\operatorname{PrPC}^{\mathrm{C}}$ was detected in patients unresponsive to neoadjuvant chemotherapy [31].

\section{2. $\operatorname{Pr} P^{C}$ and Stress-Inducible Protein 1}

Stress-inducible protein 1 (STI1), is a co-chaperonin, firstly described to stabilize the binding between Hsp 70 and 90. STI1 is mostly resident into the cytoplasm although nuclear, membrane-bound and secreted forms have also been described [151,152]. Pull-down experiments demonstrated that STI1 binds $\operatorname{PrP}^{\mathrm{C}}$ in a high affinity manner, interacting with $\operatorname{PrP}^{\mathrm{C}}$ hydrophobic region 113-128 [104]. Furthermore, it has been demonstrated that treatment of retinal neurons with STI1 or synthetic peptides matching its $\mathrm{PrP}^{\mathrm{C}}$-binding site can prevent anisomycin toxicity in vitro, indicating that STI1 represents a trigger for the anti-apoptotic activity of $\operatorname{PrP}^{\mathrm{C}}$ [106].

$\operatorname{PrP}^{\mathrm{C}}$ and STI1 are upregulated in GBM and associated with increased tumor growth and poorer survival of patients $[153,154]$. PrPC-STI1 complex has been reported to occur in GBM and, more in general, the relative abundance of $\mathrm{PrPC}^{\mathrm{C}}$ in GSCs has been hypothesized to sustain, through complexing STI1, the maintenance of stemness in astrocytic tumors. In particular, STI1 is overexpressed and secreted by GBM-associated lymphocytes, macrophages, microglia, and astrocytes, and its secretion stimulates the proliferation and migration of tumor cells, but not of normal astrocytes, only if $\operatorname{PrP}^{\mathrm{C}}$ is present and available for binding [155-158]. Moreover, $\operatorname{PrP}^{\mathrm{C}}$ contribution to stemness maintenance in GSC neurospheres, is impaired after STI1 downregulation which inhibits proliferation and self-renewal, both in vitro and in vivo [137]. Of therapeutic relevance, Martin's group, reported that the formation of $\mathrm{PrP}^{\mathrm{C}} / \mathrm{STI} 1$ complexes induces proliferation of GBM cell lines, via the activation of PI3K and ERK1/2, conversely the blockade of this interaction, depleting $\operatorname{PrP}^{\mathrm{C}}$ or using a STI1-derived peptide mimicking $\mathrm{PrP}^{\mathrm{C}}$-interacting sequence which prevents the binding, inhibited cell growth [153]. Also using in vivo experimental models, the intratumor delivery of a peptide able disrupt $\operatorname{PrP}^{\mathrm{C}} / \mathrm{STI} 1$ interaction, impaired proliferation and promoted apoptosis of GBM cells [153]. Thus, the contemporary presence of both proteins is required to promote GBM growth and this interaction could represent a potential target for innovative therapies.

\section{3. $\operatorname{Pr} P^{C}$ and Laminin}

The 37LRP and its $67 \mathrm{kDa}$ form (67LR) are both overexpressed in cancers, contributing to tumor dissemination, preventing apoptosis of cancer cells and favoring adhesion to ECM in distant tissues $[159,160]$. 37LRP is overexpressed in GBM cells than in normal astrocytes, and its activity is necessary to grant these cells with high proliferating and metastatic behavior [160]. Given the role of ECM and laminin in tumor development, it is likely that its activity in promoting tumor cell survival depends on specific receptors or scaffolding proteins present at cell membrane, including $\operatorname{Pr} \mathrm{P}^{\mathrm{C}}$ that was shown to specifically bind 37LRP $[90,94,96]$. Interestingly, also the $\operatorname{PrPC}^{\mathrm{C}}$ paralogue Doppel (Dpl, see below) interacts with 37LRP although the binding sites for $\mathrm{Dpl}$ and $\mathrm{PrPC}^{\mathrm{C}}$ were identified in different 37 LRP regions [161]. Importantly, $\mathrm{PrP}^{\mathrm{C}}$ co-localized with 37LRP in gastric carcinoma tissues and cell lines, to cause P-glycoprotein-dependent and -independent resistance to conventional anticancer agents' apoptosis [162]. In this model, 37LRP silencing significantly attenuated $\operatorname{PrP}^{\mathrm{C}}$ induced multi-drug-resistance by sensitizing vincristine-dependent apoptosis through inhibition of Ser/Thr kinase Akt activation. Thus it was proposed that the activation of the PI3K/Akt intracellular signaling 
may be required to transduce the $\mathrm{PrP}^{\mathrm{C}}$-37LPR-dependent acquisition of MDR via anti-apoptotic signals [162].

\section{4. $\operatorname{PrP}^{\mathrm{C}}$ and Notch}

Notch signaling controls multiple developmental processes and adult tissue homeostasis. Notch was shown to mediate cell-to-cell interaction signaling and to control stem cell maintenance, particularly in the CNS [163]. The activation of the four heterodimeric transmembrane receptors (Notch1-4) occurs upon their binding to a high number of specific transmembrane receptors (Delta-like-1-3-4, and Jagged-1-29) expressed by adjacent cells. Upon activation, Notch receptor family release their intracellular domains (NCID) that translocate into the nucleus to regulate the transcription of target genes (e.g., Hairy Enhancer of Split: Hes, p21/Waf1, cyclin D1 and 3, c-Myc, HER2, and Sox2) [164]. Notch1 signaling sustains the progression of some of the most aggressive human malignancies, including leukemia, pancreatic carcinomas, and GBM [164-167]. In GBM, upregulated Notch1 signaling is often identified in poorly differentiated, high grade tumors and correlates with reduced survival $[168,169]$. Human GBM tissues and cell lines overexpress Notch1 and its receptors Jagged-1 and Delta-like -1, showing also nuclear localization of NCID and enhanced expression of Notch-induced proteins, Hes1 and Hes2 $[165,170]$. Independent investigations showed that genetic or pharmacologic downregulation of Notch signaling in GSC primary cultures and cell lines promote antiproliferative and pro-apoptotic activity in vitro, impairing self-renewal and tumorigenicity $[165,168,170-174]$. Importantly, Notch1 modulation surveils the balance between self-renewal and differentiation of GSCs with the latter, enhanced by Notch1 inhibition $[173,174]$. In pancreatic carcinomas co-expression of $\mathrm{PrP}^{\mathrm{C}}$ and Notch1 correlates with poor survival. Moreover, Notch1 binding to $\mathrm{PrP}^{\mathrm{C}}$, forming a complex with filamin A (FLNA), is necessary to sustain the proliferative and invasive phenotype of pancreatic carcinoma cell lines. Accordingly, $\mathrm{PrP}^{\mathrm{C}}$ silencing reduced the expression of either Notch1 and Notch target genes, and inhibited cell proliferation and invasiveness [167].

The depletion of $\operatorname{PrP}^{\mathrm{C}}$ from neuroepithelial cells and transgenic mice [112] or its pathological conversion during mouse Scrapie infection [175] impair Notch activation and altered the early phases of embryonal neurogenesis, indicating that $\mathrm{PrP}^{\mathrm{C}}$ expression in neural progenitors is required for Notch-dependent maintenance of cell stemness. Starting from the idea that the stem component of GBM arises from glial progenitors and hijacks physiological pathways to ensure its long-term survival, $\mathrm{PrPC}^{\mathrm{C}}$ expression could represent a possible requisite for Notch signaling in tumor tissues. At this regard, the demonstration that $\mathrm{PrP}^{\mathrm{C}}$ silencing in GSCs hampers stemness and promotes differentiation [43] may suggest the possibility that impairing $\operatorname{PrP}^{\mathrm{C}}$ signaling or scaffolding activity interferes with Notch activity to induce the differentiation of GSCs in more chemotherapy-sensitive GBM cells. Further studies are warranted to address this issue.

\section{5. $\operatorname{Pr} P^{C}$ and Wnt Pathway}

Wnt family is composed by several secreted glycoproteins, which directs through the coactivator $\beta$-catenin developmental processes during embryogenesis and homeostasis and repair in adult tissues [176]. Among the pathways involved in the regulation of stem cell function, canonical $\mathrm{Wnt} / \beta$-catenin signaling is pivotal in the control of proliferation, self-renewal, stemness maintenance, and epithelial-mesenchymal transition (EMT) [177,178]. In the absence of Wnt proteins, cytosolic $\beta$-catenin is ubiquitinated and degraded by proteasome, keeping the signaling shut down. Conversely, in presence of Wnt, $\beta$-catenin accumulates in cytosol, translocates into the nucleus, and activates Wnt target gene transcription [179-182].

Dysregulation of Wnt signaling has been described in many human cancers, including GBM [183]. In human intestinal cancer cell lines (Caco-2/TC7 and SW480) and normal crypt-like cells, $\mathrm{PrPC}^{\mathrm{C}}$ interacts in cytoplasm and nucleus with the canonical Wnt pathway effectors, $\beta$-catenin and transcription factor 7-like 2 (TCF7L2), upregulating their transcription activity [184]. From a functional point of view, $\operatorname{PrP}^{\mathrm{C}}$ down-regulation, impairing Wnt signaling, inhibits the proliferation of intestinal progenitors [185]. 
Moreover, $\mathrm{PrP}^{\mathrm{C}}$ is involved in the growth and formation of intestinal organoids, since they were defective if derived from $\mathrm{PrP}^{\mathrm{C}}$-knockout mice, in which an altered nuclear $\beta$-catenin localization in intestinal crypts was observed, being likely involved in survival and proliferative mechanisms of intestinal progenitors [184]. In virtue of this evidence, $\operatorname{PrP}^{\mathrm{C}}$ is considered a modulator of Wnt signaling in proliferating intestinal epithelial cells. Moreover, $\operatorname{PrP}^{\mathrm{C}}$ interaction with Wnt and its pathway effectors was suggested as molecular correlate of oncogenic processes, since they control cell-cell junctions, and Src kinase family activity and are dysregulated during tumorigenesis [185].

\section{Pro-Prion and Cancer}

In normal cells, immature, neo-synthesized $\operatorname{PrP}^{\mathrm{C}}$ undergoes to endo-proteolytic processing, in endoplasmic reticulum and Golgi before being exposed at plasma membrane. During this process, $\operatorname{PrPC}^{\mathrm{C}}$ loses the 22 amino acid $\mathrm{N}$-terminal signal peptide and a variable $\mathrm{C}$-terminal sequence that is substituted by a glycosylphosphatidyl-inositol (GPI) anchor, and one or two N-linked oligosaccharide residues are potentially added forming mature GPI-anchored $\operatorname{PrP}^{\mathrm{C}}$ [186]. Intriguingly, a precursor form of $\mathrm{PrP}^{\mathrm{C}}$, named Pro-PrP is expressed in alternative to the mature form in different cancers, including human pancreatic ductal carcinoma and melanoma cell lines and tissues [187-189]. Pro-PrP lacks the $\mathrm{N}$-terminal signal peptide, both sugar moieties and GPI, but retains the C-terminal GPI anchor signal sequence (GPI-PSS). As a result, Pro-PrP is not anchored to the plasma membrane outer face, as mature $\mathrm{PrP}^{\mathrm{C}}$, but rather it is inserted into the phospholipid bilayer being GPI-PSS domain rich in hydrophobic amino acids (Figure 2). As a potential interactor of Pro-PrP, the actin-binding protein FLNA has been identified in melanoma cells [187]. FLNA connects the cytoskeleton with membrane proteins including integrin $\beta 1$, promoting cell motility and migration [190]. In particular, Sy et al. [191] identified a specific hydrophobic region of FLNA that recognize GPI-PSS of Pro-PrP (Figure 2). Silencing Pro-PrP in pancreatic carcinoma cell lines, although did not determine a net reduction of FLNA content, modified its intracellular distribution. While in the presence of Pro-PrP, FLNA is remarkably adherent to plasma membrane, in Pro-PrP silenced cells it is diffuse within the cytosol. In both pancreatic cancer and melanoma, the expression of Pro-PrP is associated with a higher propensity to disseminate and a significantly lower mean survival time [191]. It is important to remark that the expression of Pro-PrP was absent in non-neoplastic pancreatic tissues and it was not detectable in all tumors $(\sim 40 \%)$, but rather it was limited to specimens from most aggressive pancreatic malignancies [191]. Somehow in analogy, FLNA is not expressed in all melanomas indicating that it is not an absolute requirement for the development of these tumors, but its co-expression with Pro-PrP significantly enhance the capacity of melanoma cells to migrate [187]. Altogether, these reports indicate that the unconventional insertion of an immature form of $\mathrm{PrP}^{\mathrm{C}}$ into the plasma membrane can modify crucial interactions between cytoskeleton and extracellular environment increasing the malignant phenotype of cancer cells. The incomplete processing of $\mathrm{PrP}^{\mathrm{C}}$ in not associated to any mutation in its coding gene PRNP, rather it is plausible the intervention of mutations in any gene that encodes for proteins involved in the post-translational maturation of $\operatorname{PrPC}^{\mathrm{C}}$ [192]. 

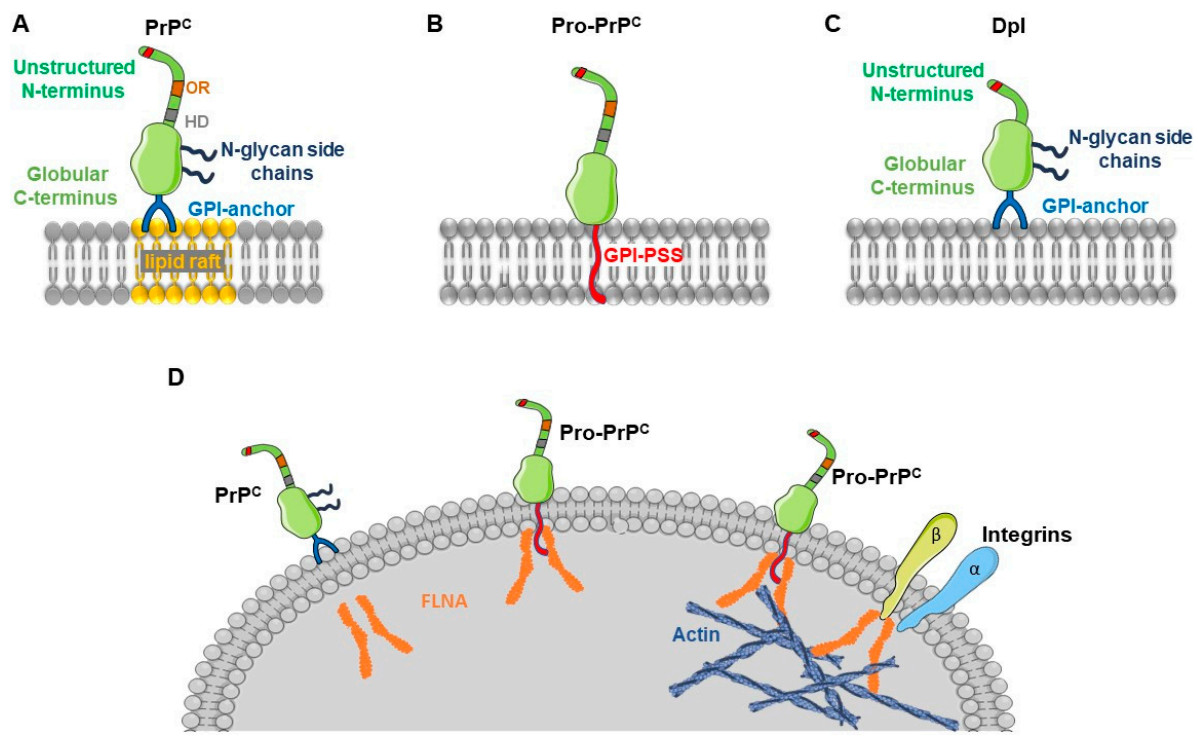

Figure 2. Structural features, cell membrane anchorage and interactions with schematic representation of $\operatorname{PrPC}$, Pro-PrP, and Dpl. (A) Cellular prion protein $\left(\mathrm{PrP}^{\mathrm{C}}\right)$ contains a N-terminal octapeptide repeat domain (OR), a highly conserved hydrophobic signal domain (HD), and a C-terminal hydrophobic region comprising a glycosylphosphatidyl-inositol (GPI) which anchors to the plasma membrane outer face in the lipid raft; (B) Pro-prion (Pro-PrP), lacks the N-terminal signal peptide, N-glycan chains and GPI, while it retains the C-terminal GPI anchor peptide signal sequence (GPI-PSS). As a result, Pro-PrP is inserted into the phospholipid bilayer by GPI-PSS rich in hydrophobic amino acids; (C) Doppel (Dpl), an $\mathrm{N}$-terminally truncated $\mathrm{PrPC}^{\mathrm{C}}$ protein lacking the octamer repeats. (D) Differently form $\operatorname{PrPC}$, Pro-PrP interacts with filamin A (FLNA) a cytoplasmic protein involved in actin organization. FLNA acts as cytolinker, which allows the binding of cell surface receptors such as integrins, to F-actin filaments, and forming an actin network responsible for the maintenance of membrane integrity, cell-cell, and cell-matrix interactions.

\section{Role of the Prion-Like Protein Doppel in Gliomas and Other Cancers}

Doppel (Dpl) is a PrP-like protein, encoded by the gene PRND, located downstream PRNP locus. Structurally, human $\mathrm{Dpl}$ and $\mathrm{PrP}^{\mathrm{C}}$ proteins are similar (Figure 2). Both molecules are glycoproteins exposed on the outside of cell membrane via a GPI anchor, whereas they display a limited amino acid homology (25\%). Although Dpl partially overlaps the C-terminal part of $\operatorname{PrP}^{\mathrm{C}}$, it does not contain the octa-repeats N-terminal region, and the amyloidogenic central sequence 106-126 [193,194]. Moreover, in contrast to $\mathrm{PrP}^{\mathrm{C}}, \mathrm{Dpl}$ expression in adults is low in brain and it is mainly confined to testis where it controls spermatogenesis $[195,196]$.

Upregulation of Dpl expression has been identified in an increasing number of cancers including leukemia, lung, colon, and astrocytomas $[136,197,198]$. Comincini et al. analyzed and compared the expression of $\mathrm{PrP}^{\mathrm{C}}$ and $\mathrm{Dpl}$ in tissue samples obtained from more than 100 astrocytomas encompassing both low and high grade glioma cell lines, as well as other malignancies (anaplastic meningiomas and gastric adenocarcinomas), using adult and fetal normal cortical tissues as controls [136,199]. Dpl was detectable in fetal normal brain, in nearly all analyzed tumors (86\%) and in most astrocytoma cell lines, with maximum levels displayed by GBM, and lowest in adult normal brain. In contrast, $\operatorname{PrP}^{\mathrm{C}}$ showed a strongest expression in normal brain tissues than in GBM samples. The increase of Dpl expression from low to high grade astrocytic tumor samples, allowed the authors to propose that Dpl might represent an early event in tumorigenesis subsequently associated with tumor grading progression.

Little information is presently available to place ectopic expression Dpl within oncogenic events, but recent evidence indicated that its expression may favor tumor cell growth and migration. Al-Hilal et al. demonstrated the presence of $\mathrm{Dpl}$ in endothelial cells in tumor-associated vessels in lung and colon 
carcinomas, and showed that Dpl interacts with vascular endothelial growth factor receptor 2 (VEGFR2) promoting angiogenesis [197]. Noteworthy, a synthetic glycosaminoglycan that binds Dpl causes antiangiogenic effects downregulating VEGFR2 expression [197]. Moreover, genetic manipulation of Dpl levels in astrocytoma cell lines affects migration ability, showing reduced cell motility induced after Dpl silencing and enhanced migratory capacity when Dpl was overexpresses [200]. In virtue of its restriction to neoplastic tissues, Dpl protein could represent either a potential biomarker or a target for selective anti-cancer therapies in the next future.

Intriguing differences between $\mathrm{PrP}^{\mathrm{C}}$ and $\mathrm{Dpl}$ concern also their intracellular localization in GBM cells. While $\operatorname{PrP}^{\mathrm{C}}$ displayed a typical expression around Golgi and at plasma membrane, Dpl showed mostly cytoplasmic distribution indicating retention into the endosomal-lysosomal system [201,202]. Such unconventional topology of Dpl is more evident in GBM than in low grade astrocytomas, in which most Dpl is tethered at plasma membrane as in normal adult testis [203]. Cancer-related differences of Dpl expression have been found also in BM from patients affected by acute myeloid leukemia [198]. It is thereafter conceivable that Dpl expression and intracellular processing may represent a novel diagnostic marker for different cancer types and its activity, when defined, a potential target for therapy $[199,203]$.

\section{Concluding Remarks and Future Perspectives}

GBM is still one of the deadliest cancers even after aggressive multimodal therapies, but the discovery of GSCs, a milestone for the comprehension of the mechanisms underlying aggressiveness and resistance to therapies, may pave the way for novel targeted therapies. Thus, the main therapeutic challenge is represented by the eradication of GSC subpopulation, which confers the tumor with aggressive behavior, including high invasive activity, and drug resistance. In this scenario, targeting selective molecular drivers which sustain GSC aggressive phenotype, in combination with standard therapies, might improve cancer patients' treatment response. $\mathrm{PrP}^{\mathrm{C}}$ is overexpressed in several cancer types, including GBM, and its content is closely related to tumor progression and poor clinical outcome. Multiple CSC-related features, such as resistance to apoptosis, CD44 expression, FLNA activity, MDR, among others, provide this tumor cell subpopulation with a survival, growth, and migratory advantage. Intriguingly, $\operatorname{PrPC}^{\mathrm{C}}$ represents a connecting factor among key stem-related molecules and functions: it interacts with CD44 fueling MDR phenotype, FLNA to promote cell migration, and also with Wnt and Notch signaling exerting pro-survival and proliferative activity.

It is important to remark that several issues are still to be addressed to definitely ascribe to $\operatorname{PrP}^{\mathrm{C}}$ a prominent role in CSC malignant behavior. For example, it seems contradictory that post-mitotic neurons have the highest $\operatorname{PrPC}^{\mathrm{C}}$ expression but do not proliferate, while GSCs proliferate only in the presence of this protein. While no explanations were provided on experimental basis, it is possible to speculate that in GSCs, at odd with mature neurons, $\mathrm{PrP}^{\mathrm{C}}$ is irregularly processed to give origin to Pro-PrP which in turn is responsible of the tumor-like behavior. While this could represent a relevant field of study, to date no data were available in GBM, possibly due to the difficulties to discriminate between the two isoforms, that besides topology show very few differences to be evaluated with standard approaches.

It has also to be understood whether $\mathrm{PrP}^{\mathrm{C}}$ and $\mathrm{Dpl}$ have complementary or independent activities in GSCs, to control of tumor cell proliferation and invasiveness.

Few attempts to translate $\mathrm{PrP}^{\mathrm{C}}$-targeted strategies in anticancer therapeutic applications have been so far published [47]. Considering that $\operatorname{PrP}^{\mathrm{C}}$ is highly expressed in adult brain and its physiological role in humans is still largely undefined, it is unlikely that a gene therapy for GBM focused on $\operatorname{PrP}^{\mathrm{C}}$ downregulation, can be devoid of general unacceptable side effects. Thus it is reasonable that effective and low-risk approaches may pursue the inhibition of $\mathrm{PrP}^{\mathrm{C}}$ and its partners' specific interactions or the downstream signal transduction pathways. For example, encouraging preclinical results have been obtained by treating GBM xenograft in mouse brains with a peptide that competes with STI1 for PrPC, resulting in an inhibition of GBM cell proliferation, without affecting normal astrocyte functioning [153]. 
Indeed, such interactions, beyond exerting a physiological control of embryonal development and tissue remodeling might also be considered a molecular signature of CSCs in adult tissues, granting a relative tumor-specific interference with GBM cell activity. In prospective, the characterization at the molecular level of $\mathrm{PrP}^{\mathrm{C}}$ interactions with its partners in tumors and normal cells or the molecules involved in signal transduction activated after the binding is an absolute requirement to develop therapeutic approaches able to discriminate between normal brain cell and tumor signaling.

In conclusion, aimed to propose a view of integration of $\mathrm{PrP}^{\mathrm{C}}$-associated functions to the GSC malignant phenotype, this review highlighted the relevance of $\mathrm{PrP}^{\mathrm{C}}$ in oncology, emphasizing its role in cancer prognosis and particularly in CSC phenotype. Future progress in understanding the function of $\mathrm{PrPC}^{\mathrm{C}}$ (and/or Pro-PrP and Dpl) could represent an effective advancement for the development and implementation of $\mathrm{PrP}^{\mathrm{C}}$-targeting therapeutic strategies improving cancer patient management.

Author Contributions: All Authors contributed to collect, select and analyze relevant scientific literature, and to wrote and revise the article.

Funding: This research was funded by Fondazione G. Celeghin (Italy) grant 2018, to TF.

Conflicts of Interest: The authors declare no conflict of interest.

\section{References}

1. Prusiner, S.B. Prions. Proc. Natl. Acad. Sci. USA 1998, 95, 13363-13383. [CrossRef] [PubMed]

2. Corsaro, A.; Thellung, S.; Villa, V.; Nizzari, M.; Florio, T. Role of prion protein aggregation in neurotoxicity. Int. J. Mol. Sci. 2012, 13, 8648-8669. [CrossRef] [PubMed]

3. Prusiner, S.B. Novel proteinaceous infectious particles cause scrapie. Science 1982, 216, 136-144. [CrossRef] [PubMed]

4. Aguzzi, A.; Polymenidou, M. Mammalian prion biology: One century of evolving concepts. Cell 2004, 116, 313-327. [CrossRef]

5. Martin-Lanneree, S.; Hirsch, T.Z.; Hernandez-Rapp, J.; Halliez, S.; Vilotte, J.L.; Launay, J.M.; Mouillet-Richard, S. PrP(C) from stem cells to cancer. Front. Cell Dev. Biol. 2014, 2, 55.

6. Blattler, T.; Brandner, S.; Raeber, A.J.; Klein, M.A.; Voigtlander, T.; Weissmann, C.; Aguzzi, A. PrP-expressing tissue required for transfer of scrapie infectivity from spleen to brain. Nature 1997, 389, 69-73. [CrossRef]

7. Weissmann, C.; Bueler, H.; Fischer, M.; Sailer, A.; Aguzzi, A.; Aguet, M. PrP-deficient mice are resistant to scrapie. Ann. N. Y. Acad. Sci. 1994, 724, 235-240. [CrossRef]

8. Brandner, S.; Raeber, A.; Sailer, A.; Blattler, T.; Fischer, M.; Weissmann, C.; Aguzzi, A. Normal host prion protein $\left(\mathrm{PrP}^{\mathrm{C}}\right)$ is required for scrapie spread within the central nervous system. Proc. Natl. Acad. Sci. USA 1996, 93, 13148-13151. [CrossRef]

9. Bremer, J.; Baumann, F.; Tiberi, C.; Wessig, C.; Fischer, H.; Schwarz, P.; Steele, A.D.; Toyka, K.V.; Nave, K.A.; Weis, J.; et al. Axonal prion protein is required for peripheral myelin maintenance. Nat. Neurosci. 2010, 13, 310-318. [CrossRef]

10. Aguzzi, A.; Baumann, F.; Bremer, J. The prion's elusive reason for being. Annu. Rev. Neurosci. 2008, 31, 439-477. [CrossRef]

11. Weissmann, C.; Flechsig, E. PrP knock-out and PrP transgenic mice in prion research. Br. Med. Bull. 2003, 66, 43-60. [CrossRef] [PubMed]

12. Miranda, A.; Pericuesta, E.; Ramirez, M.A.; Gutierrez-Adan, A. Prion protein expression regulates embryonic stem cell pluripotency and differentiation. PLOS ONE 2011, 6, e18422. [CrossRef] [PubMed]

13. Burthem, J.; Urban, B.; Pain, A.; Roberts, D.J. The normal cellular prion protein is strongly expressed by myeloid dendritic cells. Blood 2001, 98, 3733-3738. [CrossRef] [PubMed]

14. Kubosaki, A.; Yusa, S.; Nasu, Y.; Nishimura, T.; Nakamura, Y.; Saeki, K.; Matsumoto, Y.; Itohara, S.; Onodera, T. Distribution of cellular isoform of prion protein in $\mathrm{T}$ lymphocytes and bone marrow, analyzed by wild-type and prion protein gene-deficient mice. Biochem. Biophys. Res. Commun. 2001, 282, 103-107. [CrossRef]

15. McBride, P.A.; Eikelenboom, P.; Kraal, G.; Fraser, H.; Bruce, M.E. PrP protein is associated with follicular dendritic cells of spleens and lymph nodes in uninfected and scrapie-infected mice. J. Pathol. 1992, 168, 413-418. [CrossRef] 
16. Moleres, F.J.; Velayos, J.L. Expression of $\operatorname{PrP}(\mathrm{C})$ in the rat brain and characterization of a subset of cortical neurons. Brain Res. 2005, 1056, 10-21. [CrossRef]

17. Verghese-Nikolakaki, S.; Michaloudi, H.; Polymenidou, M.; Groschup, M.H.; Papadopoulos, G.C.; Sklaviadis, T. Expression of the prion protein in the rat forebrain-an immunohistochemical study. Neurosci. Lett. 1999, 272, 9-12. [CrossRef]

18. Ford, M.J.; Burton, L.J.; Morris, R.J.; Hall, S.M. Selective expression of prion protein in peripheral tissues of the adult mouse. Neuroscience 2002, 113, 177-192. [CrossRef]

19. Manson, J.; West, J.D.; Thomson, V.; McBride, P.; Kaufman, M.H.; Hope, J. The prion protein gene: A role in mouse embryogenesis? Development 1992, 115, 117-122.

20. McKinley, M.P.; Hay, B.; Lingappa, V.R.; Lieberburg, I.; Prusiner, S.B. Developmental expression of prion protein gene in brain. Dev. Biol. 1987, 121, 105-110. [CrossRef]

21. Moser, M.; Colello, R.J.; Pott, U.; Oesch, B. Developmental expression of the prion protein gene in glial cells. Neuron 1995, 14, 509-517. [CrossRef]

22. Steele, A.D.; Emsley, J.G.; Ozdinler, P.H.; Lindquist, S.; Macklis, J.D. Prion protein (PrPc) positively regulates neural precursor proliferation during developmental and adult mammalian neurogenesis. Proc. Natl. Acad. Sci. USA 2006, 103, 3416-3421. [CrossRef] [PubMed]

23. Liu, T.; Li, R.; Wong, B.S.; Liu, D.; Pan, T.; Petersen, R.B.; Gambetti, P.; Sy, M.S. Normal cellular prion protein is preferentially expressed on subpopulations of murine hemopoietic cells. J. Immunol. 2001, 166, 3733-3742. [CrossRef] [PubMed]

24. Collinge, J.; Whittington, M.A.; Sidle, K.C.; Smith, C.J.; Palmer, M.S.; Clarke, A.R.; Jefferys, J.G. Prion protein is necessary for normal synaptic function. Nature 1994, 370, 295-297. [CrossRef] [PubMed]

25. Gasperini, L.; Legname, G. Prion protein and aging. Front. Cell Dev. Biol. 2014, 2, 44. [CrossRef] [PubMed]

26. Halliez, S.; Passet, B.; Martin-Lanneree, S.; Hernandez-Rapp, J.; Laude, H.; Mouillet-Richard, S.; Vilotte, J.L.; Beringue, V. To develop with or without the prion protein. Front. Cell Dev. Biol. 2014, 2, 58. [CrossRef] [PubMed]

27. Herms, J.W.; Kretzchmar, H.A.; Titz, S.; Keller, B.U. Patch-clamp analysis of synaptic transmission to cerebellar purkinje cells of prion protein knockout mice. Eur. J. Neurosci. 1995, 7, 2508-2512. [CrossRef]

28. Zhang, C.C.; Steele, A.D.; Lindquist, S.; Lodish, H.F. Prion protein is expressed on long-term repopulating hematopoietic stem cells and is important for their self-renewal. Proc. Natl. Acad. Sci. USA 2006, 103, 2184-2189. [CrossRef]

29. Prestori, F.; Rossi, P.; Bearzatto, B.; Laine, J.; Necchi, D.; Diwakar, S.; Schiffmann, S.N.; Axelrad, H.; D’A Angelo, E. Altered neuron excitability and synaptic plasticity in the cerebellar granular layer of juvenile prion protein knock-out mice with impaired motor control. J. Neurosci. 2008, 28, 7091-7103. [CrossRef]

30. Linden, R. The Biological Function of the Prion Protein: A Cell Surface Scaffold of Signaling Modules. Front. Mol. Neurosci. 2017, 10, 77. [CrossRef]

31. Cheng, Y.; Tao, L.; Xu, J.; Li, Q.; Yu, J.; Jin, Y.; Chen, Q.; Xu, Z.; Zou, Q.; Liu, X. CD44/cellular prion protein interact in multidrug resistant breast cancer cells and correlate with responses to neoadjuvant chemotherapy in breast cancer patients. Mol. Carcinog. 2014, 53, 686-697. [CrossRef] [PubMed]

32. Du, J.; Pan, Y.; Shi, Y.; Guo, C.; Jin, X.; Sun, L.; Liu, N.; Qiao, T.; Fan, D. Overexpression and significance of prion protein in gastric cancer and multidrug-resistant gastric carcinoma cell line SGC7901/ADR. Int. J. Cancer 2005, 113, 213-220. [CrossRef] [PubMed]

33. Pan, Y.; Zhao, L.; Liang, J.; Liu, J.; Shi, Y.; Liu, N.; Zhang, G.; Jin, H.; Gao, J.; Xie, H.; et al. Cellular prion protein promotes invasion and metastasis of gastric cancer. FASEB J. 2006, 20, 1886-1888. [CrossRef] [PubMed]

34. Louis, D.N.; Perry, A.; Reifenberger, G.; von Deimling, A.; Figarella-Branger, D.; Cavenee, W.K.; Ohgaki, H.; Wiestler, O.D.; Kleihues, P.; Ellison, D.W. The 2016 World Health Organization Classification of Tumors of the Central Nervous System: A summary. Acta Neuropathol. 2016, 131, 803-820. [CrossRef]

35. Stupp, R.; Mason, W.P.; van den Bent, M.J.; Weller, M.; Fisher, B.; Taphoorn, M.J.; Belanger, K.; Brandes, A.A.; Marosi, C.; Bogdahn, U.; et al. Radiotherapy plus concomitant and adjuvant temozolomide for glioblastoma. New Engl. J. Med. 2005, 352, 987-996. [CrossRef]

36. Matarredona, E.R.; Pastor, A.M. Neural Stem Cells of the Subventricular Zone as the Origin of Human Glioblastoma Stem Cells. Therapeutic Implications. Front. Oncol. 2019, 9, 779. [CrossRef] 
37. Friedmann-Morvinski, D.; Bushong, E.A.; Ke, E.; Soda, Y.; Marumoto, T.; Singer, O.; Ellisman, M.H.; Verma, I.M. Dedifferentiation of neurons and astrocytes by oncogenes can induce gliomas in mice. Science 2012, 338, 1080-1084. [CrossRef]

38. Lee, J.H.; Lee, J.E.; Kahng, J.Y.; Kim, S.H.; Park, J.S.; Yoon, S.J.; Um, J.Y.; Kim, W.K.; Lee, J.K.; Park, J.; et al. Human glioblastoma arises from subventricular zone cells with low-level driver mutations. Nature 2018, 560, 243-247. [CrossRef]

39. Lindberg, N.; Kastemar, M.; Olofsson, T.; Smits, A.; Uhrbom, L. Oligodendrocyte progenitor cells can act as cell of origin for experimental glioma. Oncogene 2009, 28, 2266-2275. [CrossRef]

40. Florio, T.; Barbieri, F. The status of the art of human malignant glioma management: The promising role of targeting tumor-initiating cells. Drug Discov. Today 2012, 17, 1103-1110. [CrossRef]

41. Singh, S.K.; Hawkins, C.; Clarke, I.D.; Squire, J.A.; Bayani, J.; Hide, T.; Henkelman, R.M.; Cusimano, M.D.; Dirks, P.B. Identification of human brain tumour initiating cells. Nature 2004, 432, 396-401. [CrossRef] [PubMed]

42. Yadav, A.K.; Desai, N.S. Cancer Stem Cells: Acquisition, Characteristics, Therapeutic Implications, Targeting Strategies and Future Prospects. Stem Cell Rev. 2019, 15, 331-355. [CrossRef] [PubMed]

43. Corsaro, A.; Bajetto, A.; Thellung, S.; Begani, G.; Villa, V.; Nizzari, M.; Pattarozzi, A.; Solari, A.; Gatti, M.; Pagano, A.; et al. Cellular prion protein controls stem cell-like properties of human glioblastoma tumor-initiating cells. Oncotarget 2016, 7, 38638-38657. [CrossRef] [PubMed]

44. Du, L.; Rao, G.; Wang, H.; Li, B.; Tian, W.; Cui, J.; He, L.; Laffin, B.; Tian, X.; Hao, C.; et al. CD44-positive cancer stem cells expressing cellular prion protein contribute to metastatic capacity in colorectal cancer. Cancer Res. 2013, 73, 2682-2694. [CrossRef]

45. Zhuang, D.; Liu, Y.; Mao, Y.; Gao, L.; Zhang, H.; Luan, S.; Huang, F.; Li, Q. TMZ-induced PrPc/par-4 interaction promotes the survival of human glioma cells. Int. J. Cancer 2012, 130, 309-318. [CrossRef]

46. Linden, R.; Cordeiro, Y.; Lima, L.M. Allosteric function and dysfunction of the prion protein. Cell Mol. Life Sci. 2012, 69, 1105-1124. [CrossRef]

47. Santos, T.G.; Lopes, M.H.; Martins, V.R. Targeting prion protein interactions in cancer. Prion 2015, 9, $165-173$. [CrossRef]

48. Stahl, N.; Baldwin, M.A.; Hecker, R.; Pan, K.M.; Burlingame, A.L.; Prusiner, S.B. Glycosylinositol phospholipid anchors of the scrapie and cellular prion proteins contain sialic acid. Biochemistry 1992, 31, 5043-5053. [CrossRef]

49. Safar, J.; Prusiner, S.B. Molecular studies of prion diseases. Prog. Brain Res. 1998, 117, 421-434.

50. Dagher, A.; Zeighami, Y. Testing the Protein Propagation Hypothesis of Parkinson Disease. J. Exp. Neurosci. 2018, 12, 1179069518786715. [CrossRef]

51. Maniecka, Z.; Polymenidou, M. From nucleation to widespread propagation: A prion-like concept for ALS. Virus Res. 2015, 207, 94-105. [CrossRef] [PubMed]

52. Morinet, F. Prions: A model of conformational disease? Pathol. Biol. 2014, 62, 96-99. [CrossRef] [PubMed]

53. Pearce, M.M.P.; Kopito, R.R. Prion-Like Characteristics of Polyglutamine-Containing Proteins. Cold Spring Harb. Perspect. Med. 2018, 8, a024257. [CrossRef]

54. Watts, J.C.; Prusiner, S.B. beta-Amyloid Prions and the Pathobiology of Alzheimer's Disease. Cold Spring Harb. Perspect. Med. 2018, 8, a023507. [CrossRef]

55. Aulic, S.; Masperone, L.; Narkiewicz, J.; Isopi, E.; Bistaffa, E.; Ambrosetti, E.; Pastore, B.; De Cecco, E.; Scaini, D.; Zago, P.; et al. alpha-Synuclein Amyloids Hijack Prion Protein to Gain Cell Entry, Facilitate Cell-to-Cell Spreading and Block Prion Replication. Sci. Rep. 2017, 7, 10050. [CrossRef]

56. Freir, D.B.; Nicoll, A.J.; Klyubin, I.; Panico, S.; Mc Donald, J.M.; Risse, E.; Asante, E.A.; Farrow, M.A.; Sessions, R.B.; Saibil, H.R.; et al. Interaction between prion protein and toxic amyloid beta assemblies can be therapeutically targeted at multiple sites. Nat. Commun. 2011, 2, 336. [CrossRef]

57. Ondrejcak, T.; Klyubin, I.; Corbett, G.T.; Fraser, G.; Hong, W.; Mably, A.J.; Gardener, M.; Hammersley, J.; Perkinton, M.S.; Billinton, A.; et al. Cellular Prion Protein Mediates the Disruption of Hippocampal Synaptic Plasticity by Soluble Tau In Vivo. J. Neurosci. 2018, 38, 10595-10606. [CrossRef]

58. Pagano, K.; Galante, D.; D'Arrigo, C.; Corsaro, A.; Nizzari, M.; Florio, T.; Molinari, H.; Tomaselli, S.; Ragona, L. Effects of Prion Protein on Abeta42 and Pyroglutamate-Modified AbetapEpsilon3-42 Oligomerization and Toxicity. Mol. Neurobiol. 2019, 56, 1957-1971. [CrossRef] 
59. Bucciantini, M.; Giannoni, E.; Chiti, F.; Baroni, F.; Formigli, L.; Zurdo, J.; Taddei, N.; Ramponi, G.; Dobson, C.M.; Stefani, M. Inherent toxicity of aggregates implies a common mechanism for protein misfolding diseases. Nature 2002, 416, 507-511. [CrossRef]

60. Paradis, E.; Douillard, H.; Koutroumanis, M.; Goodyer, C.; LeBlanc, A. Amyloid beta peptide of Alzheimer's disease downregulates Bcl-2 and upregulates bax expression in human neurons. J. Neurosci. 1996, 16, 7533-7539. [CrossRef]

61. Thellung, S.; Corsaro, A.; Villa, V.; Venezia, V.; Nizzari, M.; Bisaglia, M.; Russo, C.; Schettini, G.; Aceto, A.; Florio, T. Amino-terminally truncated prion protein PrP90-231 induces microglial activation in vitro. Ann. N. Y. Acad. Sci. 2007, 1096, 258-270. [CrossRef] [PubMed]

62. Thellung, S.; Scoti, B.; Corsaro, A.; Villa, V.; Nizzari, M.; Gagliani, M.C.; Porcile, C.; Russo, C.; Pagano, A.; Tacchetti, C.; et al. Pharmacological activation of autophagy favors the clearing of intracellular aggregates of misfolded prion protein peptide to prevent neuronal death. Cell Death Dis. 2018, 9, 166. [CrossRef] [PubMed]

63. White, J.A.; Manelli, A.M.; Holmberg, K.H.; Van Eldik, L.J.; Ladu, M.J. Differential effects of oligomeric and fibrillar amyloid-beta 1-42 on astrocyte-mediated inflammation. Neurobiol. Dis. 2005, 18, 459-465. [CrossRef]

64. Thellung, S.; Corsaro, A.; Villa, V.; Simi, A.; Vella, S.; Pagano, A.; Florio, T. Human PrP90-231-induced cell death is associated with intracellular accumulation of insoluble and protease-resistant macroaggregates and lysosomal dysfunction. Cell Death Dis. 2011, 2, e138. [CrossRef]

65. Fioriti, L.; Angeretti, N.; Colombo, L.; De Luigi, A.; Colombo, A.; Manzoni, C.; Morbin, M.; Tagliavini, F.; Salmona, M.; Chiesa, R.; et al. Neurotoxic and gliotrophic activity of a synthetic peptide homologous to Gerstmann-Straussler-Scheinker disease amyloid protein. J. Neurosci. 2007, 27, 1576-1583. [CrossRef]

66. Florio, T.; Grimaldi, M.; Scorziello, A.; Salmona, M.; Bugiani, O.; Tagliavini, F.; Forloni, G.; Schettini, G. Intracellular calcium rise through L-type calcium channels, as molecular mechanism for prion protein fragment 106-126-induced astroglial proliferation. Biochem. Biophys. Res. Commun. 1996, 228, 397-405. [CrossRef]

67. Forloni, G.; Angeretti, N.; Chiesa, R.; Monzani, E.; Salmona, M.; Bugiani, O.; Tagliavini, F. Neurotoxicity of a prion protein fragment. Nature 1993, 362, 543-546. [CrossRef]

68. Villa, V.; Thellung, S.; Corsaro, A.; Novelli, F.; Tasso, B.; Colucci-D'Amato, L.; Gatta, E.; Tonelli, M.; Florio, T. Celecoxib Inhibits Prion Protein 90-231-Mediated Pro-inflammatory Responses in Microglial Cells. Mol. Neurobiol. 2016, 53, 57-72. [CrossRef]

69. Thellung, S.; Gatta, E.; Pellistri, F.; Villa, V.; Corsaro, A.; Nizzari, M.; Robello, M.; Florio, T. Different Molecular Mechanisms Mediate Direct or Glia-Dependent Prion Protein Fragment 90-231 Neurotoxic Effects in Cerebellar Granule Neurons. Neurotox Res. 2017, 32, 381-397. [CrossRef]

70. Corsaro, A.; Thellung, S.; Chiovitti, K.; Villa, V.; Simi, A.; Raggi, F.; Paludi, D.; Russo, C.; Aceto, A.; Florio, T. Dual modulation of ERK1/2 and p38 MAP kinase activities induced by minocycline reverses the neurotoxic effects of the prion protein fragment 90-231. Neurotox Res. 2009, 15, 138-154. [CrossRef]

71. Thellung, S.; Villa, V.; Corsaro, A.; Arena, S.; Millo, E.; Damonte, G.; Benatti, U.; Tagliavini, F.; Florio, T.; Schettini, G. p38 MAP kinase mediates the cell death induced by PrP106-126 in the SH-SY5Y neuroblastoma cells. Neurobiol. Dis. 2002, 9, 69-81. [CrossRef] [PubMed]

72. Villa, V.; Thellung, S.; Bajetto, A.; Gatta, E.; Robello, M.; Novelli, F.; Tasso, B.; Tonelli, M.; Florio, T. Novel celecoxib analogues inhibit glial production of prostaglandin E2, nitric oxide, and oxygen radicals reverting the neuroinflammatory responses induced by misfolded prion protein fragment 90-231 or lipopolysaccharide. Pharmacol. Res. 2016, 113, 500-514. [CrossRef] [PubMed]

73. Thellung, S.; Villa, V.; Corsaro, A.; Pellistri, F.; Venezia, V.; Russo, C.; Aceto, A.; Robello, M.; Florio, T. ERK1/2 and p38 MAP kinases control prion protein fragment 90-231-induced astrocyte proliferation and microglia activation. Glia 2007, 55, 1469-1485. [CrossRef] [PubMed]

74. Fang, C.; Wu, B.; Le, N.T.T.; Imberdis, T.; Mercer, R.C.C.; Harris, D.A. Prions activate a p38 MAPK synaptotoxic signaling pathway. PLoS Pathog. 2018, 14, e1007283. [CrossRef] [PubMed]

75. Didonna, A.; Legname, G. Aberrant ERK 1/2 complex activation and localization in scrapie-infected GT1-1 cells. Mol. Neurodegener 2010, 5, 29. [CrossRef]

76. Nordstrom, E.; Fisone, G.; Kristensson, K. Opposing effects of ERK and p38-JNK MAP kinase pathways on formation of prions in GT1-1 cells. FASEB J. 2009, 23, 613-622. [CrossRef] 
77. Manson, J.C.; Clarke, A.R.; Hooper, M.L.; Aitchison, L.; McConnell, I.; Hope, J. 129/Ola mice carrying a null mutation in PrP that abolishes mRNA production are developmentally normal. Mol. Neurobiol. 1994, 8, 121-127. [CrossRef]

78. Mobley, W.C.; Neve, R.L.; Prusiner, S.B.; McKinley, M.P. Nerve growth factor increases mRNA levels for the prion protein and the beta-amyloid protein precursor in developing hamster brain. Proc. Natl. Acad. Sci. USA 1988, 85, 9811-9815. [CrossRef]

79. Horiuchi, M.; Yamazaki, N.; Ikeda, T.; Ishiguro, N.; Shinagawa, M. A cellular form of prion protein $(\operatorname{PrPC})$ exists in many non-neuronal tissues of sheep. J. Gen. Virol. 1995, 76, 2583-2587. [CrossRef]

80. Dodelet, V.C.; Cashman, N.R. Prion protein expression in human leukocyte differentiation. Blood 1998, 91, 1556-1561. [CrossRef]

81. Lee, Y.J.; Baskakov, I.V. The cellular form of the prion protein guides the differentiation of human embryonic stem cells into neuron-, oligodendrocyte-, and astrocyte-committed lineages. Prion 2014, 8, 266-275. [CrossRef] [PubMed]

82. Peralta, O.A.; Huckle, W.R.; Eyestone, W.H. Expression and knockdown of cellular prion protein $\left(\operatorname{PrP} \mathrm{P}^{\mathrm{C}}\right)$ in differentiating mouse embryonic stem cells. Differentiation 2011, 81, 68-77. [CrossRef] [PubMed]

83. Tabar, V.; Panagiotakos, G.; Greenberg, E.D.; Chan, B.K.; Sadelain, M.; Gutin, P.H.; Studer, L. Migration and differentiation of neural precursors derived from human embryonic stem cells in the rat brain. Nat. Biotechnol. 2005, 23, 601-606. [CrossRef]

84. Bove-Fenderson, E.; Urano, R.; Straub, J.E.; Harris, D.A. Cellular prion protein targets amyloid-beta fibril ends via its C-terminal domain to prevent elongation. J. Biol. Chem. 2017, 292, 16858-16871. [CrossRef]

85. De Cecco, E.; Legname, G. The role of the prion protein in the internalization of alpha-synuclein amyloids. Prion 2018, 12, 23-27. [CrossRef]

86. Martins, V.R.; Beraldo, F.H.; Hajj, G.N.; Lopes, M.H.; Lee, K.S.; Prado, M.A.; Linden, R. Prion protein: Orchestrating neurotrophic activities. Curr. Issues Mol. Biol. 2010, 12, 63-86.

87. Nieznanski, K. Interactions of prion protein with intracellular proteins: So many partners and no consequences? Cell. Mol. Neurobiol. 2010, 30, 653-666. [CrossRef]

88. Gardiner, N.J. Integrins and the extracellular matrix: Key mediators of development and regeneration of the sensory nervous system. Dev. Neurobiol. 2011, 71, 1054-1072. [CrossRef]

89. Mercurio, A.M. Laminin receptors: Achieving specificity through cooperation. Trends. Cell Biol. 1995, 5, 419-423. [CrossRef]

90. Graner, E.; Mercadante, A.F.; Zanata, S.M.; Forlenza, O.V.; Cabral, A.L.; Veiga, S.S.; Juliano, M.A.; Roesler, R.; Walz, R.; Minetti, A.; et al. Cellular prion protein binds laminin and mediates neuritogenesis. Brain Res. Mol. Brain Res. 2000, 76, 85-92. [CrossRef]

91. Loubet, D.; Dakowski, C.; Pietri, M.; Pradines, E.; Bernard, S.; Callebert, J.; Ardila-Osorio, H.; Mouillet-Richard, S.; Launay, J.M.; Kellermann, O.; et al. Neuritogenesis: The prion protein controls beta1 integrin signaling activity. FASEB J. 2012, 26, 678-690. [CrossRef] [PubMed]

92. Graner, E.; Mercadante, A.F.; Zanata, S.M.; Martins, V.R.; Jay, D.G.; Brentani, R.R. Laminin-induced PC-12 cell differentiation is inhibited following laser inactivation of cellular prion protein. FEBS Lett. 2000, 482, 257-260. [CrossRef]

93. Hajj, G.N.; Lopes, M.H.; Mercadante, A.F.; Veiga, S.S.; da Silveira, R.B.; Santos, T.G.; Ribeiro, K.C.; Juliano, M.A.; Jacchieri, S.G.; Zanata, S.M.; et al. Cellular prion protein interaction with vitronectin supports axonal growth and is compensated by integrins. J. Cell Sci. 2007, 120, 1915-1926. [CrossRef] [PubMed]

94. Hundt, C.; Peyrin, J.M.; Haik, S.; Gauczynski, S.; Leucht, C.; Rieger, R.; Riley, M.L.; Deslys, J.P.; Dormont, D.; Lasmezas, C.I.; et al. Identification of interaction domains of the prion protein with its $37-\mathrm{kDa} / 67-\mathrm{kDa}$ laminin receptor. Embo. J. 2001, 20, 5876-5886. [CrossRef]

95. Rieger, R.; Edenhofer, F.; Lasmezas, C.I.; Weiss, S. The human 37-kDa laminin receptor precursor interacts with the prion protein in eukaryotic cells. Nat. Med. 1997, 3, 1383-1388. [CrossRef]

96. Gauczynski, S.; Peyrin, J.M.; Haik, S.; Leucht, C.; Hundt, C.; Rieger, R.; Krasemann, S.; Deslys, J.P.; Dormont, D.; Lasmezas, C.I.; et al. The $37-\mathrm{kDa} / 67-\mathrm{kDa}$ laminin receptor acts as the cell-surface receptor for the cellular prion protein. Embo. J. 2001, 20, 5863-5875. [CrossRef]

97. Crossin, K.L.; Krushel, L.A. Cellular signaling by neural cell adhesion molecules of the immunoglobulin superfamily. Dev. Dyn. 2000, 218, 260-279. [CrossRef] 
98. Schmitt-Ulms, G.; Legname, G.; Baldwin, M.A.; Ball, H.L.; Bradon, N.; Bosque, P.J.; Crossin, K.L.; Edelman, G.M.; DeArmond, S.J.; Cohen, F.E.; et al. Binding of neural cell adhesion molecules (N-CAMs) to the cellular prion protein. J. Mol. Biol. 2001, 314, 1209-1225. [CrossRef]

99. Santuccione, A.; Sytnyk, V.; Leshchyns'ka, I.; Schachner, M. Prion protein recruits its neuronal receptor NCAM to lipid rafts to activate p59fyn and to enhance neurite outgrowth. J. Cell Biol. 2005, 169, 341-354. [CrossRef]

100. Slapsak, U.; Salzano, G.; Amin, L.; Abskharon, R.N.; Ilc, G.; Zupancic, B.; Biljan, I.; Plavec, J.; Giachin, G.; Legname, G. The N Terminus of the Prion Protein Mediates Functional Interactions with the Neuronal Cell Adhesion Molecule (NCAM) Fibronectin Domain. J. Biol. Chem. 2016, 291, 21857-21868. [CrossRef]

101. Mehrabian, M.; Brethour, D.; Wang, H.; Xi, Z.; Rogaeva, E.; Schmitt-Ulms, G. The Prion Protein Controls Polysialylation of Neural Cell Adhesion Molecule 1 during Cellular Morphogenesis. PLoS ONE 2015, 10, e0133741. [CrossRef] [PubMed]

102. Prodromidou, K.; Papastefanaki, F.; Sklaviadis, T.; Matsas, R. Functional cross-talk between the cellular prion protein and the neural cell adhesion molecule is critical for neuronal differentiation of neural stem/precursor cells. Stem Cells 2014, 32, 1674-1687. [CrossRef] [PubMed]

103. Mouillet-Richard, S.; Ermonval, M.; Chebassier, C.; Laplanche, J.L.; Lehmann, S.; Launay, J.M.; Kellermann, O. Signal transduction through prion protein. Science 2000, 289, 1925-1928. [CrossRef] [PubMed]

104. Zanata, S.M.; Lopes, M.H.; Mercadante, A.F.; Hajj, G.N.; Chiarini, L.B.; Nomizo, R.; Freitas, A.R.; Cabral, A.L.; Lee, K.S.; Juliano, M.A.; et al. Stress-inducible protein 1 is a cell surface ligand for cellular prion that triggers neuroprotection. Embo. J. 2002, 21, 3307-3316. [CrossRef]

105. Landemberger, M.C.; de Oliveira, G.P.; Machado, C.F.; Gollob, K.J.; Martins, V.R. Loss of STI1-mediated neuronal survival and differentiation in disease-associated mutations of prion protein. J. Neurochem. 2018, 145, 409-416. [CrossRef]

106. Chiarini, L.B.; Freitas, A.R.; Zanata, S.M.; Brentani, R.R.; Martins, V.R.; Linden, R. Cellular prion protein transduces neuroprotective signals. Embo. J. 2002, 21, 3317-3326. [CrossRef]

107. Lopes, M.H.; Hajj, G.N.; Muras, A.G.; Mancini, G.L.; Castro, R.M.; Ribeiro, K.C.; Brentani, R.R.; Linden, R.; Martins, V.R. Interaction of cellular prion and stress-inducible protein 1 promotes neuritogenesis and neuroprotection by distinct signaling pathways. J. Neurosci. 2005, 25, 11330-11339. [CrossRef]

108. Roffe, M.; Beraldo, F.H.; Bester, R.; Nunziante, M.; Bach, C.; Mancini, G.; Gilch, S.; Vorberg, I.; Castilho, B.A.; Martins, V.R.; et al. Prion protein interaction with stress-inducible protein 1 enhances neuronal protein synthesis via mTOR. Proc. Natl. Acad. Sci. USA 2010, 107, 13147-13152. [CrossRef]

109. Santos, T.G.; Silva, I.R.; Costa-Silva, B.; Lepique, A.P.; Martins, V.R.; Lopes, M.H. Enhanced neural progenitor/stem cells self-renewal via the interaction of stress-inducible protein 1 with the prion protein. Stem Cells 2011, 29, 1126-1136. [CrossRef]

110. Irvin, D.K.; Zurcher, S.D.; Nguyen, T.; Weinmaster, G.; Kornblum, H.I. Expression patterns of Notch1, Notch2, and Notch3 suggest multiple functional roles for the Notch-DSL signaling system during brain development. J. Comp. Neurol. 2001, 436, 167-181. [CrossRef]

111. Lutolf, S.; Radtke, F.; Aguet, M.; Suter, U.; Taylor, V. Notch1 is required for neuronal and glial differentiation in the cerebellum. Development 2002, 129, 373-385. [PubMed]

112. Martin-Lanneree, S.; Halliez, S.; Hirsch, T.Z.; Hernandez-Rapp, J.; Passet, B.; Tomkiewicz, C.; Villa-Diaz, A.; Torres, J.M.; Launay, J.M.; Beringue, V.; et al. The Cellular Prion Protein Controls Notch Signaling in Neural Stem/Progenitor Cells. Stem Cells 2017, 35, 754-765. [CrossRef] [PubMed]

113. Jeffrey, M.; McGovern, G.; Goodsir, C.M.; Brown, K.L.; Bruce, M.E. Sites of prion protein accumulation in scrapie-infected mouse spleen revealed by immuno-electron microscopy. J. Pathol. 2000, 191, 323-332. [CrossRef]

114. Kitamoto, T.; Muramoto, T.; Mohri, S.; Doh-Ura, K.; Tateishi, J. Abnormal isoform of prion protein accumulates in follicular dendritic cells in mice with Creutzfeldt-Jakob disease. J. Virol. 1991, 65, 6292-6295.

115. Brown, K.L.; Stewart, K.; Ritchie, D.L.; Mabbott, N.A.; Williams, A.; Fraser, H.; Morrison, W.I.; Bruce, M.E. Scrapie replication in lymphoid tissues depends on prion protein-expressing follicular dendritic cells. Nat. Med. 1999, 5, 1308-1312. [CrossRef]

116. O’Rourke, K.I.; Huff, T.P.; Leathers, C.W.; Robinson, M.M.; Gorham, J.R. SCID mouse spleen does not support scrapie agent replication. J. Gen. Virol. 1994, 75, 1511-1514. [CrossRef] 
117. Fraser, H.; Brown, K.L.; Stewart, K.; McConnell, I.; McBride, P.; Williams, A. Replication of scrapie in spleens of SCID mice follows reconstitution with wild-type mouse bone marrow. J. Gen. Virol. 1996, 77, 1935-1940. [CrossRef]

118. Montrasio, F.; Frigg, R.; Glatzel, M.; Klein, M.A.; Mackay, F.; Aguzzi, A.; Weissmann, C. Impaired prion replication in spleens of mice lacking functional follicular dendritic cells. Science 2000, 288, 1257-1259. [CrossRef]

119. Zivny, J.H.; Gelderman, M.P.; Xu, F.; Piper, J.; Holada, K.; Simak, J.; Vostal, J.G. Reduced erythroid cell and erythropoietin production in response to acute anemia in prion protein-deficient (Prnp-/-) mice. Blood Cells Mol. Dis. 2008, 40, 302-307. [CrossRef]

120. Ballerini, C.; Gourdain, P.; Bachy, V.; Blanchard, N.; Levavasseur, E.; Gregoire, S.; Fontes, P.; Aucouturier, P.; Hivroz, C.; Carnaud, C. Functional implication of cellular prion protein in antigen-driven interactions between T cells and dendritic cells. J. Immunol. 2006, 176, 7254-7262. [CrossRef]

121. de Almeida, C.J.; Chiarini, L.B.; da Silva, J.P.; PM, E.S.; Martins, M.A.; Linden, R. The cellular prion protein modulates phagocytosis and inflammatory response. J. Leukoc. Biol. 2005, 77, 238-246. [CrossRef] [PubMed]

122. Siberchicot, C.; Gault, N.; Dechamps, N.; Barroca, V.; Aguzzi, A.; Romeo, P.H.; Radicella, J.P.; Bravard, A.; Bernardino-Sgherri, J. Prion protein deficiency impairs hematopoietic stem cells determination and sensitizes myeloid progenitors to irradiation. Haematologica 2019. [CrossRef] [PubMed]

123. Toledo-Guzman, M.E.; Bigoni-Ordonez, G.D.; Ibanez Hernandez, M.; Ortiz-Sanchez, E. Cancer stem cell impact on clinical oncology. World, J. Stem Cells 2018, 10, 183-195. [CrossRef] [PubMed]

124. Wurth, R.; Barbieri, F.; Pattarozzi, A.; Gaudenzi, G.; Gatto, F.; Fiaschi, P.; Ravetti, J.L.; Zona, G.; Daga, A.; Persani, L.; et al. Phenotypical and Pharmacological Characterization of Stem-Like Cells in Human Pituitary Adenomas. Mol. Neurobiol. 2017, 54, 4879-4895. [CrossRef] [PubMed]

125. Galli, R.; Binda, E.; Orfanelli, U.; Cipelletti, B.; Gritti, A.; De Vitis, S.; Fiocco, R.; Foroni, C.; Dimeco, F.; Vescovi, A. Isolation and characterization of tumorigenic, stem-like neural precursors from human glioblastoma. Cancer Res. 2004, 64, 7011-7021. [CrossRef]

126. Yuan, X.; Curtin, J.; Xiong, Y.; Liu, G.; Waschsmann-Hogiu, S.; Farkas, D.L.; Black, K.L.; Yu, J.S. Isolation of cancer stem cells from adult glioblastoma multiforme. Oncogene 2004, 23, 9392-9400. [CrossRef]

127. Brandao, M.; Simon, T.; Critchley, G.; Giamas, G. Astrocytes the rising stars of the glioblastoma microenvironment. Glia 2019, 67, 779-790. [CrossRef]

128. D'Alessio, A.; Proietti, G.; Sica, G.; Scicchitano, B.M. Pathological and Molecular Features of Glioblastoma and Its Peritumoral Tissue. Cancers 2019, 11, 469. [CrossRef]

129. Perus, L.J.M.; Walsh, L.A. Microenvironmental Heterogeneity in Brain Malignancies. Front. Immunol. 2019, 10, 2294. [CrossRef]

130. Wurth, R.; Bajetto, A.; Harrison, J.K.; Barbieri, F.; Florio, T. CXCL12 modulation of CXCR4 and CXCR7 activity in human glioblastoma stem-like cells and regulation of the tumor microenvironment. Front. Cell. Neurosci. 2014, 8, 144 .

131. Aderetti, D.A.; Hira, V.V.V.; Molenaar, R.J.; van Noorden, C.J.F. The hypoxic peri-arteriolar glioma stem cell niche, an integrated concept of five types of niches in human glioblastoma. Biochim. Biophys. Acta Rev. Cancer 2018, 1869, 346-354. [CrossRef] [PubMed]

132. Filatova, A.; Acker, T.; Garvalov, B.K. The cancer stem cell niche(s): The crosstalk between glioma stem cells and their microenvironment. Biochim. Biophys. Acta 2013, 1830, 2496-2508. [CrossRef] [PubMed]

133. Zhao, Y.; You, H.; Liu, F.; An, H.; Shi, Y.; Yu, Q.; Fan, D. Differentially expressed gene profiles between multidrug resistant gastric adenocarcinoma cells and their parental cells. Cancer Lett. 2002, 185, 211-218. [CrossRef]

134. Diarra-Mehrpour, M.; Arrabal, S.; Jalil, A.; Pinson, X.; Gaudin, C.; Pietu, G.; Pitaval, A.; Ripoche, H.; Eloit, M.; Dormont, D.; et al. Prion protein prevents human breast carcinoma cell line from tumor necrosis factor alpha-induced cell death. Cancer Res. 2004, 64, 719-727. [CrossRef]

135. Li, Q.Q.; Cao, X.X.; Xu, J.D.; Chen, Q.; Wang, W.J.; Tang, F.; Chen, Z.Q.; Liu, X.P.; Xu, Z.D. The role of $\mathrm{P}$-glycoprotein/cellular prion protein interaction in multidrug-resistant breast cancer cells treated with paclitaxel. Cell Mol. Life Sci. 2009, 66, 504-515. [CrossRef]

136. Comincini, S.; Facoetti, A.; Del Vecchio, I.; Peoc'h, K.; Laplanche, J.L.; Magrassi, L.; Ceroni, M.; Ferretti, L.; Nano, R. Differential expression of the prion-like protein doppel gene (PRND) in astrocytomas: A new molecular marker potentially involved in tumor progression. Anticancer Res. 2004, 24, 1507-1517. 
137. Iglesia, R.P.; Prado, M.B.; Cruz, L.; Martins, V.R.; Santos, T.G.; Lopes, M.H. Engagement of cellular prion protein with the co-chaperone Hsp70/90 organizing protein regulates the proliferation of glioblastoma stem-like cells. Stem Cell Res. 2017, 8, 76. [CrossRef]

138. Kikuchi, Y.; Kakeya, T.; Yamazaki, T.; Takekida, K.; Nakamura, N.; Matsuda, H.; Takatori, K.; Tanimura, A.; Tanamoto, K.; Sawada, J. G1-dependent prion protein expression in human glioblastoma cell line T98G. Biol. Pharm. Bull. 2002, 25, 728-733. [CrossRef]

139. Hinton, C.; Antony, H.; Hashimi, S.M.; Munn, A.; Wei, M.Q. Significance of prion and prion-like proteins in cancer development, progression and multi-drug resistance. Curr. Cancer Drug Targets 2013, 13, 895-904. [CrossRef]

140. Hirose, Y.; Berger, M.S.; Pieper, R.O. p53 effects both the duration of G2/M arrest and the fate of temozolomide-treated human glioblastoma cells. Cancer Res. 2001, 61, 1957-1963.

141. Johannessen, T.C.; Bjerkvig, R.; Tysnes, B.B. DNA repair and cancer stem-like cells-potential partners in glioma drug resistance? Cancer Treat. Rev. 2008, 34, 558-567. [CrossRef] [PubMed]

142. Cheema, S.K.; Mishra, S.K.; Rangnekar, V.M.; Tari, A.M.; Kumar, R.; Lopez-Berestein, G. Par-4 transcriptionally regulates Bcl-2 through a WT1-binding site on the bcl-2 promoter. J. Biol. Chem. 2003, 278, 19995-20005. [CrossRef] [PubMed]

143. Huet, S.; Groux, H.; Caillou, B.; Valentin, H.; Prieur, A.M.; Bernard, A. CD44 contributes to T cell activation. J. Immunol 1989, 143, 798-801. [PubMed]

144. Goodison, S.; Urquidi, V.; Tarin, D. CD44 cell adhesion molecules. Mol. Pathol. 1999, 52, 189-196. [CrossRef] [PubMed]

145. Hou, C.; Ishi, Y.; Motegi, H.; Okamoto, M.; Ou, Y.; Chen, J.; Yamaguchi, S. Overexpression of CD44 is associated with a poor prognosis in grade II/III gliomas. J. Neurooncol. 2019, 145, 201-210. [CrossRef]

146. Dong, Q.; Li, Q.; Wang, M.; Hu, J.; Dai, J.; Niu, L.; Yuan, G.; Pan, Y. Elevated CD44 expression predicts poor prognosis in patients with low-grade glioma. Oncol. Lett. 2019, 18, 3698-3704. [CrossRef]

147. Guadagno, E.; Borrelli, G.; Califano, M.; Cali, G.; Solari, D.; Del Basso De Caro, M. Immunohistochemical expression of stem cell markers CD44 and nestin in glioblastomas: Evaluation of their prognostic significance. Pathol. Res. Pr. 2016, 212, 825-832. [CrossRef]

148. Nishikawa, M.; Inoue, A.; Ohnishi, T.; Kohno, S.; Ohue, S.; Matsumoto, S.; Suehiro, S.; Yamashita, D.; Ozaki, S.; Watanabe, H.; et al. Significance of Glioma Stem-Like Cells in the Tumor Periphery That Express High Levels of CD44 in Tumor Invasion, Early Progression, and Poor Prognosis in Glioblastoma. Stem Cells Int. 2018, 2018, 5387041. [CrossRef]

149. Johansson, E.; Grassi, E.S.; Pantazopoulou, V.; Tong, B.; Lindgren, D.; Berg, T.J.; Pietras, E.J.; Axelson, H.; Pietras, A. CD44 Interacts with HIF-2alpha to Modulate the Hypoxic Phenotype of Perinecrotic and Perivascular Glioma Cells. Cell Rep. 2017, 20, 1641-1653. [CrossRef]

150. Wang, H.H.; Liao, C.C.; Chow, N.H.; Huang, L.L.; Chuang, J.I.; Wei, K.C.; Shin, J.W. Whether CD44 is an applicable marker for glioma stem cells. Am. J. Transl. Res. 2017, 9, 4785-4806.

151. Johnson, B.D.; Schumacher, R.J.; Ross, E.D.; Toft, D.O. Hop modulates Hsp70/Hsp90 interactions in protein folding. J. Biol. Chem. 1998, 273, 3679-3686. [CrossRef] [PubMed]

152. Kravats, A.N.; Hoskins, J.R.; Reidy, M.; Johnson, J.L.; Doyle, S.M.; Genest, O.; Masison, D.C.; Wickner, S. Functional and physical interaction between yeast Hsp90 and Hsp70. Proc. Natl. Acad. Sci. USA 2018, 115, E2210-E2219. [CrossRef] [PubMed]

153. Lopes, M.H.; Santos, T.G.; Rodrigues, B.R.; Queiroz-Hazarbassanov, N.; Cunha, I.W.; Wasilewska-Sampaio, A.P.; Costa-Silva, B.; Marchi, F.A.; Bleggi-Torres, L.F.; Sanematsu, P.I.; et al. Disruption of prion protein-HOP engagement impairs glioblastoma growth and cognitive decline and improves overall survival. Oncogene 2015, 34, 3305-3314. [CrossRef] [PubMed]

154. Baindur-Hudson, S.; Edkins, A.L.; Blatch, G.L. Hsp70/Hsp90 organising protein (hop): Beyond interactions with chaperones and prion proteins. Subcell Biochem. 2015, 78, 69-90.

155. Erlich, R.B.; Kahn, S.A.; Lima, F.R.; Muras, A.G.; Martins, R.A.; Linden, R.; Chiarini, L.B.; Martins, V.R.; Moura Neto, V. STI1 promotes glioma proliferation through MAPK and PI3K pathways. Glia 2007, 55, 1690-1698. [CrossRef]

156. Fonseca, A.C.; Romao, L.; Amaral, R.F.; Assad Kahn, S.; Lobo, D.; Martins, S.; Marcondes de Souza, J.; Moura-Neto, V.; Lima, F.R. Microglial stress inducible protein 1 promotes proliferation and migration in human glioblastoma cells. Neuroscience 2012, 200, 130-141. [CrossRef] 
157. Lima, F.R.; Arantes, C.P.; Muras, A.G.; Nomizo, R.; Brentani, R.R.; Martins, V.R. Cellular prion protein expression in astrocytes modulates neuronal survival and differentiation. J. Neurochem. 2007, 103, 2164-2176. [CrossRef]

158. Carvalho da Fonseca, A.C.; Wang, H.; Fan, H.; Chen, X.; Zhang, I.; Zhang, L.; Lima, F.R.; Badie, B. Increased expression of stress inducible protein 1 in glioma-associated microglia/macrophages. J. Neuroimmunol. 2014, 274, 71-77. [CrossRef]

159. Susantad, T.; Smith, D.R. siRNA-mediated silencing of the $37 / 67-k D a$ high affinity laminin receptor in Hep3B cells induces apoptosis. Cell Mol. Biol. Lett. 2008, 13, 452-464. [CrossRef]

160. Wu, H.; Li, J.; Xu, D.; Jv, D.; Meng, X.; Qiao, P.; Cui, T.; Shi, B. The 37-kDa laminin receptor precursor regulates the malignancy of human glioma cells. Cell Biochem. Funct. 2016, 34, 516-521. [CrossRef]

161. Yin, S.M.; Sy, M.S.; Yang, H.Y.; Tien, P. Interaction of Doppel with the full-length laminin receptor precursor protein. Arch. Biochem. Biophys. 2004, 428, 165-169. [CrossRef] [PubMed]

162. Luo, G.; Wang, W.; Wu, Q.; Lu, Y.; Su, T.; Gu, N.; Li, K.; Wang, J.; Du, R.; Zhao, X.; et al. MGr1-Antigen/37 $\mathrm{kDa}$ laminin receptor precursor promotes cellular prion protein induced multi-drug-resistance of gastric cancer. Oncotarget 2017, 8, 71630-71641. [CrossRef] [PubMed]

163. Imayoshi, I.; Sakamoto, M.; Yamaguchi, M.; Mori, K.; Kageyama, R. Essential roles of Notch signaling in maintenance of neural stem cells in developing and adult brains. J. Neurosci. 2010, 30, 3489-3498. [CrossRef] [PubMed]

164. Bazzoni, R.; Bentivegna, A. Role of Notch Signaling Pathway in Glioblastoma Pathogenesis. Cancers 2019, 11, 292. [CrossRef] [PubMed]

165. Purow, B.W.; Haque, R.M.; Noel, M.W.; Su, Q.; Burdick, M.J.; Lee, J.; Sundaresan, T.; Pastorino, S.; Park, J.K.; Mikolaenko, I.; et al. Expression of Notch-1 and its ligands, Delta-like-1 and Jagged-1, is critical for glioma cell survival and proliferation. Cancer Res. 2005, 65, 2353-2363. [CrossRef] [PubMed]

166. Wang, Y.; Hou, H.; Li, M.; Yang, Y.; Sun, L. Anticancer effect of eupatilin on glioma cells through inhibition of the Notch-1 signaling pathway. Mol. Med. Rep. 2016, 13, 1141-1146. [CrossRef]

167. Wang, Y.; Yu, S.; Huang, D.; Cui, M.; Hu, H.; Zhang, L.; Wang, W.; Parameswaran, N.; Jackson, M.; Osborne, B.; et al. Cellular Prion Protein Mediates Pancreatic Cancer Cell Survival and Invasion through Association with and Enhanced Signaling of Notch1. Am. J. Pathol. 2016, 186, 2945-2956. [CrossRef]

168. Zhang, X.P.; Zheng, G.; Zou, L.; Liu, H.L.; Hou, L.H.; Zhou, P.; Yin, D.D.; Zheng, Q.J.; Liang, L.; Zhang, S.Z.; et al. Notch activation promotes cell proliferation and the formation of neural stem cell-like colonies in human glioma cells. Mol. Cell Biochem. 2008, 307, 101-108. [CrossRef]

169. Han, N.; Hu, G.; Shi, L.; Long, G.; Yang, L.; Xi, Q.; Guo, Q.; Wang, J.; Dong, Z.; Zhang, M. Notch1 ablation radiosensitizes glioblastoma cells. Oncotarget 2017, 8, 88059-88068. [CrossRef]

170. Kanamori, M.; Kawaguchi, T.; Nigro, J.M.; Feuerstein, B.G.; Berger, M.S.; Miele, L.; Pieper, R.O. Contribution of Notch signaling activation to human glioblastoma multiforme. J. Neurosurg. 2007, 106, 417-427. [CrossRef]

171. Fan, X.; Khaki, L.; Zhu, T.S.; Soules, M.E.; Talsma, C.E.; Gul, N.; Koh, C.; Zhang, J.; Li, Y.M.; Maciaczyk, J.; et al. NOTCH pathway blockade depletes CD133-positive glioblastoma cells and inhibits growth of tumor neurospheres and xenografts. Stem Cells 2010, 28, 5-16. [CrossRef] [PubMed]

172. Fan, X.; Matsui, W.; Khaki, L.; Stearns, D.; Chun, J.; Li, Y.M.; Eberhart, C.G. Notch pathway inhibition depletes stem-like cells and blocks engraftment in embryonal brain tumors. Cancer Res. 2006, 66, 7445-7452. [CrossRef] [PubMed]

173. Kristoffersen, K.; Nedergaard, M.K.; Villingshoj, M.; Borup, R.; Broholm, H.; Kjaer, A.; Poulsen, H.S.; Stockhausen, M.T. Inhibition of Notch signaling alters the phenotype of orthotopic tumors formed from glioblastoma multiforme neurosphere cells but does not hamper intracranial tumor growth regardless of endogene Notch pathway signature. Cancer Biol. 2014, 15, 862-877. [CrossRef] [PubMed]

174. Kristoffersen, K.; Villingshoj, M.; Poulsen, H.S.; Stockhausen, M.T. Level of Notch activation determines the effect on growth and stem cell-like features in glioblastoma multiforme neurosphere cultures. Cancer Biol. 2013, 14, 625-637. [CrossRef]

175. Hirsch, T.Z.; Martin-Lanneree, S.; Reine, F.; Hernandez-Rapp, J.; Herzog, L.; Dron, M.; Privat, N.; Passet, B.; Halliez, S.; Villa-Diaz, A.; et al. Epigenetic Control of the Notch and Eph Signaling Pathways by the Prion Protein: Implications for Prion Diseases. Mol. Neurobiol. 2019, 56, 2159-2173. [CrossRef] [PubMed]

176. Logan, C.Y.; Nusse, R. The Wnt signaling pathway in development and disease. Annu. Rev. Cell Dev. Biol. 2004, 20, 781-810. [CrossRef] 
177. Reya, T.; Clevers, H. Wnt signalling in stem cells and cancer. Nature 2005, 434, 843-850. [CrossRef]

178. Varnat, F.; Zacchetti, G.; Ruiz i Altaba, A. Hedgehog pathway activity is required for the lethality and intestinal phenotypes of mice with hyperactive Wnt signaling. Mech. Dev. 2010, 127, 73-81. [CrossRef]

179. He, X.C.; Zhang, J.; Tong, W.G.; Tawfik, O.; Ross, J.; Scoville, D.H.; Tian, Q.; Zeng, X.; He, X.; Wiedemann, L.M.; et al. signaling inhibits intestinal stem cell self-renewal through suppression of Wnt-beta-catenin signaling. Nat. Genet. 2004, 36, 1117-1121. [CrossRef]

180. Komiya, Y.; Habas, R. Wnt signal transduction pathways. Organogenesis 2008, 4, 68-75. [CrossRef]

181. MacDonald, B.T.; Tamai, K.; He, X. Wnt/beta-catenin signaling: Components, mechanisms, and diseases. Dev. Cell 2009, 17, 9-26. [CrossRef] [PubMed]

182. Nusse, R. Wnt signaling. Cold Spring Harb Perspect Biol. 2012, 4, a011163. [CrossRef] [PubMed]

183. Tompa, M.; Kalovits, F.; Nagy, A.; Kalman, B. Contribution of the Wnt Pathway to Defining Biology of Glioblastoma. Neuromol. Med. 2018, 20, 437-451. [CrossRef] [PubMed]

184. Besnier, L.S.; Cardot, P.; Da Rocha, B.; Simon, A.; Loew, D.; Klein, C.; Riveau, B.; Lacasa, M.; Clair, C.; Rousset, M.; et al. The cellular prion protein PrPc is a partner of the Wnt pathway in intestinal epithelial cells. Mol. Biol. Cell 2015, 26, 3313-3328. [CrossRef] [PubMed]

185. Rousset, M.; Leturque, A.; Thenet, S. The nucleo-junctional interplay of the cellular prion protein: A new partner in cancer-related signaling pathways? Prion 2016, 10, 143-152. [CrossRef] [PubMed]

186. Haraguchi, T.; Fisher, S.; Olofsson, S.; Endo, T.; Groth, D.; Tarentino, A.; Borchelt, D.R.; Teplow, D.; Hood, L.; Burlingame, A.; et al. Asparagine-linked glycosylation of the scrapie and cellular prion proteins. Arch. Biochem. Biophys. 1989, 274, 1-13. [CrossRef]

187. Li, C.; Yu, S.; Nakamura, F.; Pentikainen, O.T.; Singh, N.; Yin, S.; Xin, W.; Sy, M.S. Pro-prion binds filamin A, facilitating its interaction with integrin beta1, and contributes to melanomagenesis. J. Biol. Chem. 2010, 285, 30328-30339. [CrossRef]

188. Li, C.; Yu, S.; Nakamura, F.; Yin, S.; Xu, J.; Petrolla, A.A.; Singh, N.; Tartakoff, A.; Abbott, D.W.; Xin, W.; et al. Binding of pro-prion to filamin A disrupts cytoskeleton and correlates with poor prognosis in pancreatic cancer. J. Clin. Investig. 2009, 119, 2725-2736. [CrossRef]

189. Li, C.; Xin, W.; Sy, M.S. Binding of pro-prion to filamin A: By design or an unfortunate blunder. Oncogene 2010, 29, 5329-5345. [CrossRef]

190. Kim, H.; McCulloch, C.A. Filamin A mediates interactions between cytoskeletal proteins that control cell adhesion. FEBS Lett. 2011, 585, 18-22. [CrossRef]

191. Sy, M.S.; Li, C.; Yu, S.; Xin, W. The fatal attraction between pro-prion and filamin A: Prion as a marker in human cancers. Biomark Med. 2010, 4, 453-464. [CrossRef] [PubMed]

192. Yang, L.; Gao, Z.; Hu, L.; Wu, G.; Yang, X.; Zhang, L.; Zhu, Y.; Wong, B.S.; Xin, W.; Sy, M.S.; et al. Glycosylphosphatidylinositol Anchor Modification Machinery Deficiency Is Responsible for the Formation of Pro-Prion Protein (PrP) in BxPC-3 Protein and Increases Cancer Cell Motility. J. Biol. Chem. 2016, 291, 3905-3917. [CrossRef] [PubMed]

193. Lu, K.; Wang, W.; Xie, Z.; Wong, B.S.; Li, R.; Petersen, R.B.; Sy, M.S.; Chen, S.G. Expression and structural characterization of the recombinant human doppel protein. Biochemistry 2000, 39, 13575-13583. [CrossRef] [PubMed]

194. Silverman, G.L.; Qin, K.; Moore, R.C.; Yang, Y.; Mastrangelo, P.; Tremblay, P.; Prusiner, S.B.; Cohen, F.E.; Westaway, D. Doppel is an N-glycosylated, glycosylphosphatidylinositol-anchored protein. Expression in testis and ectopic production in the brains of Prnp(0/0) mice predisposed to Purkinje cell loss. J. Biol. Chem. 2000, 275, 26834-26841. [PubMed]

195. Behrens, A.; Genoud, N.; Naumann, H.; Rulicke, T.; Janett, F.; Heppner, F.L.; Ledermann, B.; Aguzzi, A. Absence of the prion protein homologue Doppel causes male sterility. Embo. J. 2002, 21,3652-3658. [CrossRef]

196. Moore, R.C.; Lee, I.Y.; Silverman, G.L.; Harrison, P.M.; Strome, R.; Heinrich, C.; Karunaratne, A.; Pasternak, S.H.; Chishti, M.A.; Liang, Y.; et al. Ataxia in prion protein (PrP)-deficient mice is associated with upregulation of the novel PrP-like protein doppel. J. Mol. Biol. 1999, 292, 797-817. [CrossRef]

197. Al-Hilal, T.A.; Chung, S.W.; Choi, J.U.; Alam, F.; Park, J.; Kim, S.W.; Kim, S.Y.; Ahsan, F.; Kim, I.S.; Byun, Y. Targeting prion-like protein doppel selectively suppresses tumor angiogenesis. J. Clin. Investig. 2016, 126, 1251-1266. [CrossRef] 
198. Travaglino, E.; Comincini, S.; Benatti, C.; Azzalin, A.; Nano, R.; Rosti, V.; Ferretti, L.; Invernizzi, R. Overexpression of the Doppel protein in acute myeloid leukaemias and myelodysplastic syndromes. Br. J. Haematol. 2005, 128, 877-884. [CrossRef]

199. Comincini, S.; Ferrara, V.; Arias, A.; Malovini, A.; Azzalin, A.; Ferretti, L.; Benericetti, E.; Cardarelli, M.; Gerosa, M.; Passarin, M.G.; et al. Diagnostic value of PRND gene expression profiles in astrocytomas: Relationship to tumor grades of malignancy. Oncol. Rep. 2007, 17, 989-996. [CrossRef]

200. Azzalin, A.; Sbalchiero, E.; Barbieri, G.; Palumbo, S.; Muzzini, C.; Comincini, S. The doppel (Dpl) protein influences in vitro migration capability in astrocytoma-derived cells. Cell Oncol. 2008, 30, 491-501.

201. Comincini, S.; Chiarelli, L.R.; Zelini, P.; Del Vecchio, I.; Azzalin, A.; Arias, A.; Ferrara, V.; Rognoni, P.; Dipoto, A.; Nano, R.; et al. Nuclear mRNA retention and aberrant doppel protein expression in human astrocytic tumor cells. Oncol. Rep. 2006, 16, 1325-1332. [CrossRef] [PubMed]

202. Sbalchiero, E.; Azzalin, A.; Palumbo, S.; Barbieri, G.; Arias, A.; Simonelli, L.; Ferretti, L.; Comincini, S. Altered cellular distribution and sub-cellular sorting of doppel (Dpl) protein in human astrocytoma cell lines. Cell Oncol. 2008, 30, 337-347. [PubMed]

203. Rognoni, P.; Chiarelli, L.R.; Comincini, S.; Azzalin, A.; Miracco, C.; Valentini, G. Biochemical signatures of doppel protein in human astrocytomas to support prediction in tumor malignancy. J. Biomed. Biotechnol. 2010, 2010, 301067. [CrossRef] [PubMed]

(C) 2019 by the authors. Licensee MDPI, Basel, Switzerland. This article is an open access article distributed under the terms and conditions of the Creative Commons Attribution (CC BY) license (http://creativecommons.org/licenses/by/4.0/). 